\title{
SIMULATION OF STORM PEAKS AND STORM VOLUMES FOR SELECTED SUBBASINS IN THE WEST FORK TRINITY RIVER BASIN, TEXAS, WATER YEARS 1993-94
}

By Timothy H. Raines

U.S. GEOLOGICAL SURVEY

Water-Resources Investigations Report 96-4110

Prepared in cooperation with the

TARRANT COUNTY WATER CONTROL AND IMPROVEMENT DISTRICT NO. 1 


\section{U.S. DEPARTMENT OF THE INTERIOR \\ BRUCE BABBITT, Secretary}

U.S. GEOLOGICAL SURVEY

Gordon P. Eaton, Director

Any use of trade, product, or firm names is for descriptive purposes only and does not imply endorsement by the U.S. Government.

For additional information write to:

District Chief

U.S. Geological Survey

8011 Cameron Rd.

Austin, TX 78754-3898
Copies of this report can be purchased from:

U.S. Geological Survey

Branch of Information Services

Box 25286

Denver, CO 80225-0286 


\section{CONTENTS}

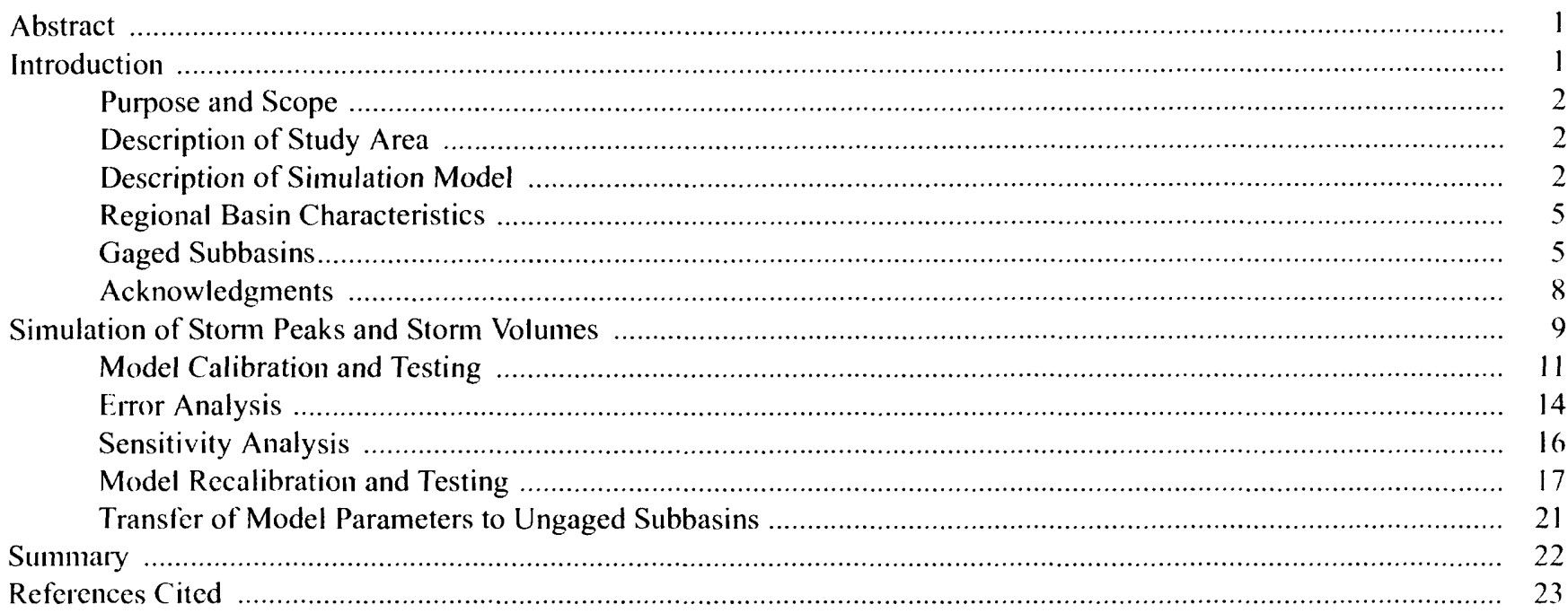

\section{FIGURES}

1. Map showing location of West Fork Trinity River Basin

2. Map showing major subbasins in the West Fork Trinity River Basin ......................................................

3-7. Maps showing data-collection network for the:

3. Beans Creek subbasin

4. Big Creek subbasin

5. Garrett Creek subbasin

6. Salt Creek subbasin

7. Walnut Creek subbasin

8. Measured and simulated hydrographs for Walnut Creek at Reno, Texas, September 13-14, 1993

10-13. Graphs showing:

10. Measured times of peak and simulated times of peak using calibrated parameters 2 2 2 5 5 8 9

西

11. Measured storm peaks and simulated storm peaks using calibrated parameters ...

Measured storm volumes and simulated storm volumes using calibrated parameters ........................ 16

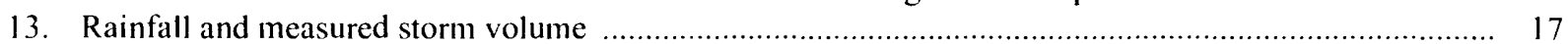

14. Measured and simulated hydrographs for Beans Creek at Wizard Wells, Texas, February 14-16, 1993 .......... 19

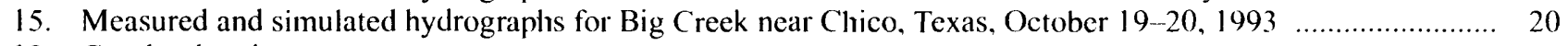

16-18. Graphs showing:

16. Measured times of peak and simulated times of peak using recalibrated parameters .......................... 21

17. Measured storm peaks and simulated storm peaks using recalibrated parameters .............................. 22

18. Measured storm volumes and simulated storm volumes using recalibrated parameters ....................... 23

\section{TABLES}

1. Process-related model parameters for the Hydrologic Simulation Program - FORTRAN ............................. 24

2. Basin-related model parameters for the Hydrologic Simulation Program--FORTRAN ................................. 24

3. Gaged subbasins in the West Fork Trinity River Basin upstream from Lake Worth .................................... 25

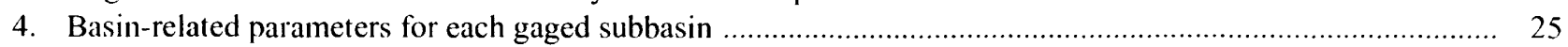

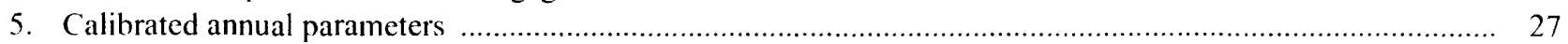

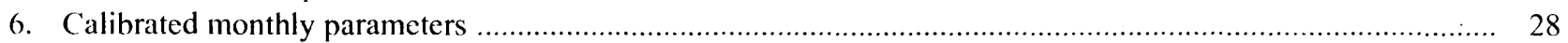

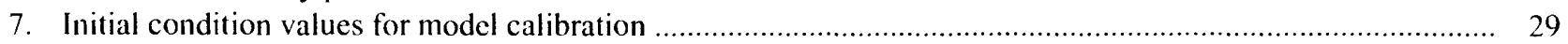


8. Measured and simulated storm peaks and storm volumes using calibrated parameters

9. Mean absolute errors and biases of storm peaks and storm volumes using calibrated parameters

10. Monthly distribution of errors of storm peaks and storm volumes using calibrated parameters

11. Sensitivity of selected parameters

12. Recalibrated annual parameters

13. Recalibrated monthly parameters

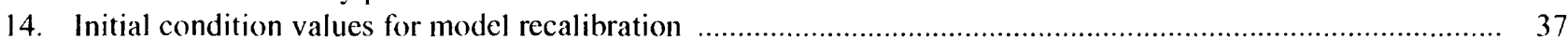

15. Measured and simulated storm peaks and storm volumes using recalibrated parameters ............................. 38

16. Mean absolute errors and biases of storm peaks and storm volumes using recalibrated parameters ................. 41

17. Monthly distribution of errors of storm peaks and storm volumes using recalibrated parameters 


\title{
Simulation of Storm Peaks and Storm Volumes for Selected Subbasins in the West Fork Trinity River Basin, Texas, Water Years 1993-94
}

\author{
By Timothy H. Raines
}

\section{Abstract}

A model parameter set for use with the Hydrologic Simulation Program -FORTRAN watershed model was developed to simulate storm peaks and storm volumes for the 28 subbasins of the West Fork Trinity River Basin upstream from Lake Worth, northwest of Fort Worth, Texas, from the calibration and testing of 5 gaged subbasins. These parameters can be transferred to the 23 ungaged subbasins. The model simulates storm runoff for a channel-routing model that can be used to improve reservoir operation during floods in the basin.

Rainfall and runoff data were collected from October 1, 1992, to September 30, 1994. A total of 55 storms were recorded at the 5 streamgage stations during the 24 months. Twelve different pervious land segments were defined based on types of soil, land cover, and watershed slope. A total of 20 process-related parameters were defined for each land segment, and 6 basin-related parameters were defined for each stream reach.

The mean absolute errors for the 5 subbasins for simulation of storm peaks range from 48.0 to 470 percent and for simulation of storm volumes range from 34.4 to 416 percent. A sensitivity analysis was done to determine what a change in a parameter value has on the largest storm peak and on the total storm volume. The model then was recalibrated and tested on the basis of the analysis of the sensitivity of parameters and on the analysis of the errors from the initial model calibration and testing. The mean absolute errors for the $5 \mathrm{sub}$ basins using the recalibrated parameters for simu- lation of storm peaks range from 47.1 to 297 percent, and for simulation of storm volumes range from 27.6 to 193 percent.

The model produced better results for simulation of the larger storm peaks and storm volumes than for simulation of the smaller storm peaks and storm volumes, especially after an extended period of no runoff. The same range in errors can be expected when transferring the parameters to the 23 ungaged subbasins. Additional data collection and model refinement could decrease the range of expected model errors. More storm data and improved discharge rating curves could result in model parameters that account for the wide seasonal variations in runoff in the study area.

\section{INTRODUCTION}

Recent flooding (1990) in the West Fork Trinity River Basin upstream from Lake Worth, northwest of Fort Worth, Texas, has caused extensive damage to public and private property and has resulted in a need for improved flood forecasting to better manage reservoir operation. Although simulation models for flood routing in the main channel of the West Fork Trinity River and in reservoirs are available for the basin, rainfallrunoff data for the subbasins are lacking. Accurate estimates of storm runoff for the 28 subbasins that drain into the West Fork Trinity River Basin upstream from Lake Worth are needed for input into a channel-routing model. Previous attempts to use event-based simulation models have been unsatisfactory because the models were unable to accurately estimate the volume, magnitude, and timing of peak flows. A range in evaporation, infiltration, and storage capacities measured throughout the year results in a wide variation of storm runoff. Therefore, continuous-simulation models could provide 
a better representation of seasonal variations of rainfall and runoff than event-based simulation models.

In 1991, the U.S. Geological Survey, in cooperation with the Tarrant County Water Control and Improvement District No. 1, began a study to develop a model parameter set to simulate storm peaks and volumes for selected subbasins in the West Fork Trinity River Basin. Specific objectives of the study were to (1) develop a set of parameters for a continuoussimulation model from the calibration and testing of 5 gaged subbasins; (2) transfer the parameter set to the remaining 23 ungaged subbasins of the West Fork Trinity River Basin upstream from Lake Worth; and (3) use the model to simulate storm runoff in the basin to improve reservoir operation during floods.

\section{Purpose and Scope}

This report describes the simulation of storm peaks and storm volumes for 5 gaged subbasins in the West Fork Trinity River Basin upstream from Lake Worth. Rainfall and runoff data from 55 storms used in this report were collected during water years 1993 94 (October 1. 1992, to September 30, 1994). Each subbasin was characterized by twelve various pervious land segments that were defined based on types of soil, land cover, and watershed slope and was subdivided into two to three reaches for input to a continuous-simulation model. A total of 20 processrelated parameters were defined for each land segment, and 6 basin-related parameters were defined for each stream reach.

\section{Description of Study Area}

The study area is in the north-central part of Texas (fig. 1). The West Fork Trinity River Basin upstream from Lake Worth drains about 2,100 square miles $\left(\mathrm{mi}^{2}\right)$. The basin is divided into 28 major subbasins that range from 15.8 to $227 \mathrm{mi}^{2}$ and contains three major reservoirs: Lake Bridgeport, Eagle Mountain Lake, and Lake Worth (fig. 2).

The study area is characterized by a moderate climate with hot, dry summers; warm, wet autumns; cool, dry winters; and warm. wet springs. Mean annual temperature for the study area is $64^{\circ} \mathrm{F}$ (degrees Fahrenhcii) with monthly means ranging from $44^{\circ} \mathrm{F}$ in January $1085^{\circ} \mathrm{F}$ in July. Mcan annual precipitation, mostly as rainfall, totals about 28 inches (in.) (National Oceanic and Atmospheric Administration, 1990). Rainfall in the study area is generated from frontal sys- tems and convective heating. The frontal systems in spring and fall produce moderate- to high-intensity, long-duration storms that generally result in the maximum storm peaks for the year. Convective thunderstorms produce widely scaltered, high-intensity, shortduration storms that occur mostly in summer.

Soils in the basin consist mainly of the Windthorst-Duffau and the Truce-Bonti primary series. The Windthorst-Duffau series consists of deep, sandyloam soils formed in weakly cemented sandstone that has moderately low permeability. A representative soil profile consists of 10 in. of sandy loam overlying $30 \mathrm{in}$. of sandy-clay loam. The Truce-Bonti series consists of deep, clay-loam soils formed in strongly cemented sandstone and clay that has low permeability. A representative soil profile consists of $9 \mathrm{in}$. of fine sandy loam overlying 31 in. of clay (U.S. Department of Agriculture, Soil Conservation Service, 1977, 1978, 1981). Land cover is characterized by alternating prairies and woodlands consisting of mesquite, juniper, shinnery oak, post oak, and live oak trees. The rangeland is used for grazing beef and dairy cattle, whereas the cropland is used for growing peanuts and grain sorghum. The average watershed slope varies from gently sloping to sloping, or about 2 to 5 percent.

\section{Description of Simulation Model}

The Hydrologic Simulation Program FORTRAN (HSPF) (U.S. Environmental Protection Agency, 1992) is a continuous-simulation model using a conceptual framework to represent infiltration, evaporation, interception storage, surface runoff, interflow, and base flow on a pervious land segment (PERLND) and retention storage and surface runoff on an impervious land segment (IMPLND). Each user-defined land segment represents its own unique hydrologic response system based on soil type, land cover, watershed slope, or other important basin characteristic. These land segments do not need to be contiguous. The runoff from each land segment is moved through a system of reaches or reservoirs (RCHRES) using storage routing. In addition to runoff, water-quality concentrations for several constituents can be simulated for each land segment.

The HSPF model uses input from three types of data: time series, process-related model parameters, and basin-related model parameters. Continuous time series of precipitation and potential evaporation are needed to execute the model. Point-precipitation data 


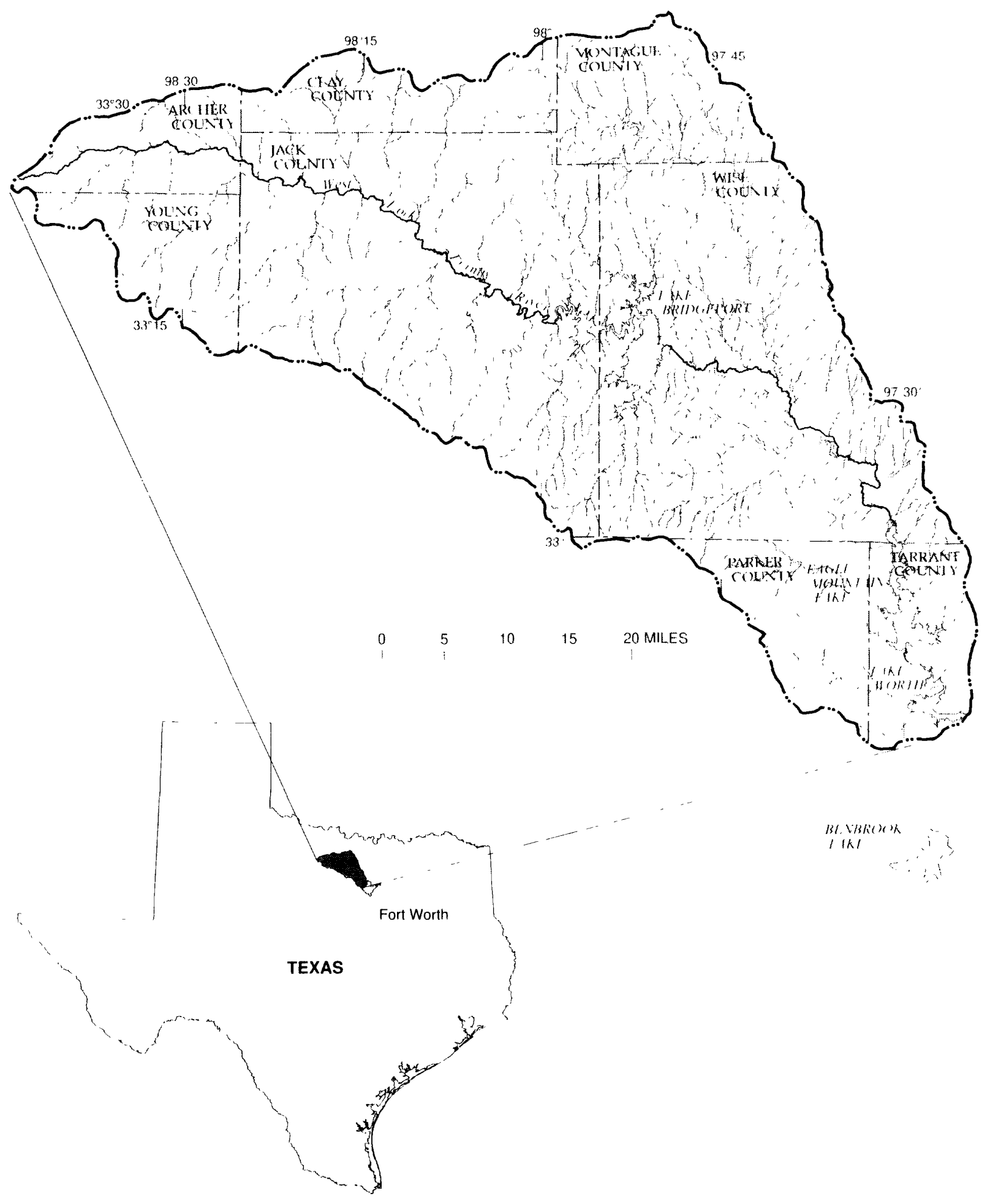

LOCATION MAP

Figure 1. Location of West Fork Trinity River Basin. 


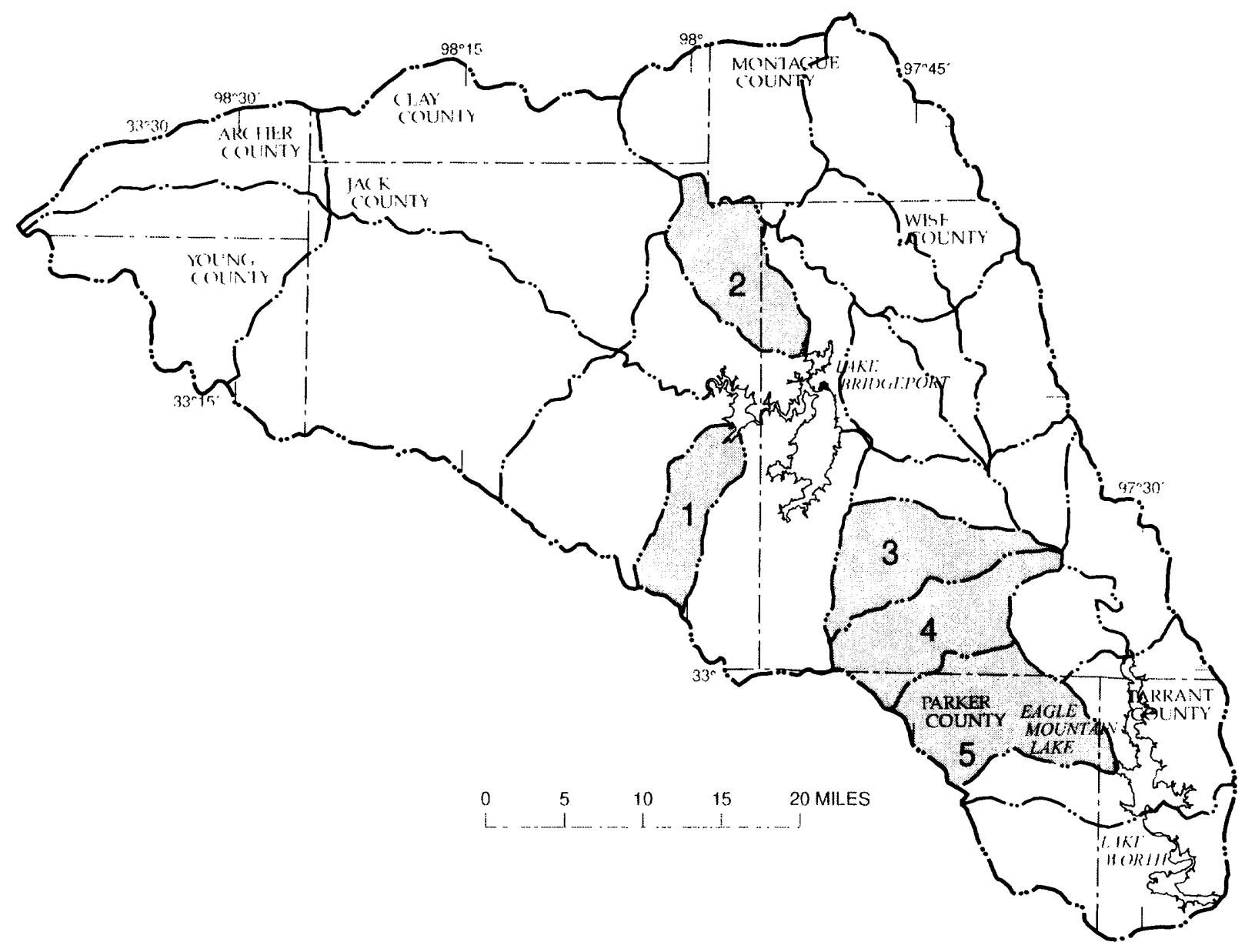

\section{EXPLANATION}

| Ungaged subhasin

1 Gaged subbasin

1 Beans Creek subbasin

2 Big Creek subbasin

3 Garrett Creek subbasin

4 Salt Creek subbasin

5 Walnut Creek subbasin

-..- Subbasin boundary

Figure 2. Major subbasins in the West Fork Trinity River Basin.

measured by raingages are assumed to be uniform over a land segment. Potential evaporation data can be estimated from measured pan evaporation or computed using minimum and maximum temperatures. Measured runoff time series are used for model calibration and testing.
The 20 process-related model parameters listed in table 1 (at end of report) represent the physical processes of soil infiltration, soil moisture, evapotranspiration (ET), interception storage of plants, interflow recession, ground-water recession, and surface runoff for each land segment. The process-related model 
parameters for each land segment are adjusted to calibrate the model. The following parameters can be varied by month to account for seasonal variations: interception storage capacity (CEPSC), interflow inflow (INTFW), interflow recession rate (IRC), lower zone ET (LZETP), Manning's n for assumed overland flow plane (NSUR), and upper zone nominal storage (UZSN). The HSPF users manual (U.S. Environmental Protection Agency, 1992) provides a more complete description of each parameter.

The six basin-related model parameters listed in table 2 (at end of report) define the areal extent of each land segment, the reach length, and a table of values (FTABLE) of surface area, volume, and discharge as a function of depth for each reach of the watershed. These parameters represent the physical characteristics of each reach of a watershed and generally remain unchanged during calibration of the model.

Only one parameter set was developed for the 5 gaged subbasins to establish a level of confidence in transferring the parameter set to the 23 ungaged subbasins. Accuracy might be improved by calibrating each basin separately; but calibrating each basin separately would not provide a method for or confidence in transferring the parameters to the ungaged subbasins. In this study, two gaged subbasins were used for model calibration and the remaining three gaged subbasins were used for model testing. Error and sensitivity analyses were done. The calibration of HSPF was facilitated by the use of an expert system interface developed by Lumb and others (1994) that provided graphics, error statistics, and advice on which parameters to change.

\section{Regional Basin Characteristics}

The HSPF simulation run time increases proportionately to the number of land segments used; therefore, the number of land segments used needs to be such that a balance is struck between accuracy and computation time. Geographic information system (GIS) coverages of soil type, land cover, watershed slope, roads, and urban areas were analyzed by the cooperator for the entire basin to identify basin characteristics that could produce unique hydrologic responses (Alice Godbey, Tarrant County Water Control and Improvement District No. 1, written commun., 1993). Two groups of soil types, three groups of land cover, and two groups of watershed slopes were identified to represent 12 unique pervious land segments. The two groups of soil types were classified as low permeability (less than 2 inches per hour [in/hr]) and moderately low permeability (greater than $2 \mathrm{in} / \mathrm{hr}$ ). Crop, forest, and pasture characterized the three main land-cover groups. The watershed-slope group was divided into flat (slopes less than 3 percent) and steep (slopes greater than 3 percent). Because less than 2 percent of the entire watershed contains roads and urban areas, no impervious land segments were used.

\section{Gaged Subbasins}

Because minimal data existed for the 28 subbasins, a network of raingage and streamgage stations was installed to obtain rainfall and runoff data to calibrate and test the continuous-simulation model. Five of the 28 subbasins were selected for data collection on the basis of their representative soil type, land cover, and slope for the entire study area. The drainage areas for the 5 gaged subbasins range from 36.0 to $62.6 \mathrm{mi}^{2}$ (table 3 at end of report).

Each gaged subbasin was subdivided into two to three reaches (figs. 3-7). The basin-related model parameters for each gaged subbasin are listed in table 4 (at end of report). The areas of each pervious land segment were computed for each reach using GIS (Alice Godbey, Tarrant County Water Control and Improvement District No. 1, written commun., 1993). Beans Creek and Big Creek consist mostly of soil group 1, whereas Garrett Creek, Salt Creek, and Walnut Creek consist mostly of soil group 2 . The three land-cover groups are fairly well distributed in each of the five subbasins. Most watershed slopes are flat (less than 3 percent) for the five subbasins. The reach length was measured from U.S. Geological Survey (USGS) 7.5 minute quadrangle topographic maps. A channel cross section was measured for each reach to compute the FTABLE values (David Marshall, Tarrant County Water Control and Improvement District No. 1, written commun., 1993). The surface area as a function of depth was computed by multiplying the average channel width by the reach length. The volume as a function of depth was computed by multiplying the average cross-sectional area by the reach length. The discharge as a function of depth was either taken from the rating table at the streamgage station or was estimated using Manning's equation (Chow and others, 1988). The basin-related parameters were not adjusted during the model calibration process.

Flood-stage data were measured at the five subbasins with float, tape, and stilling-well systems that 


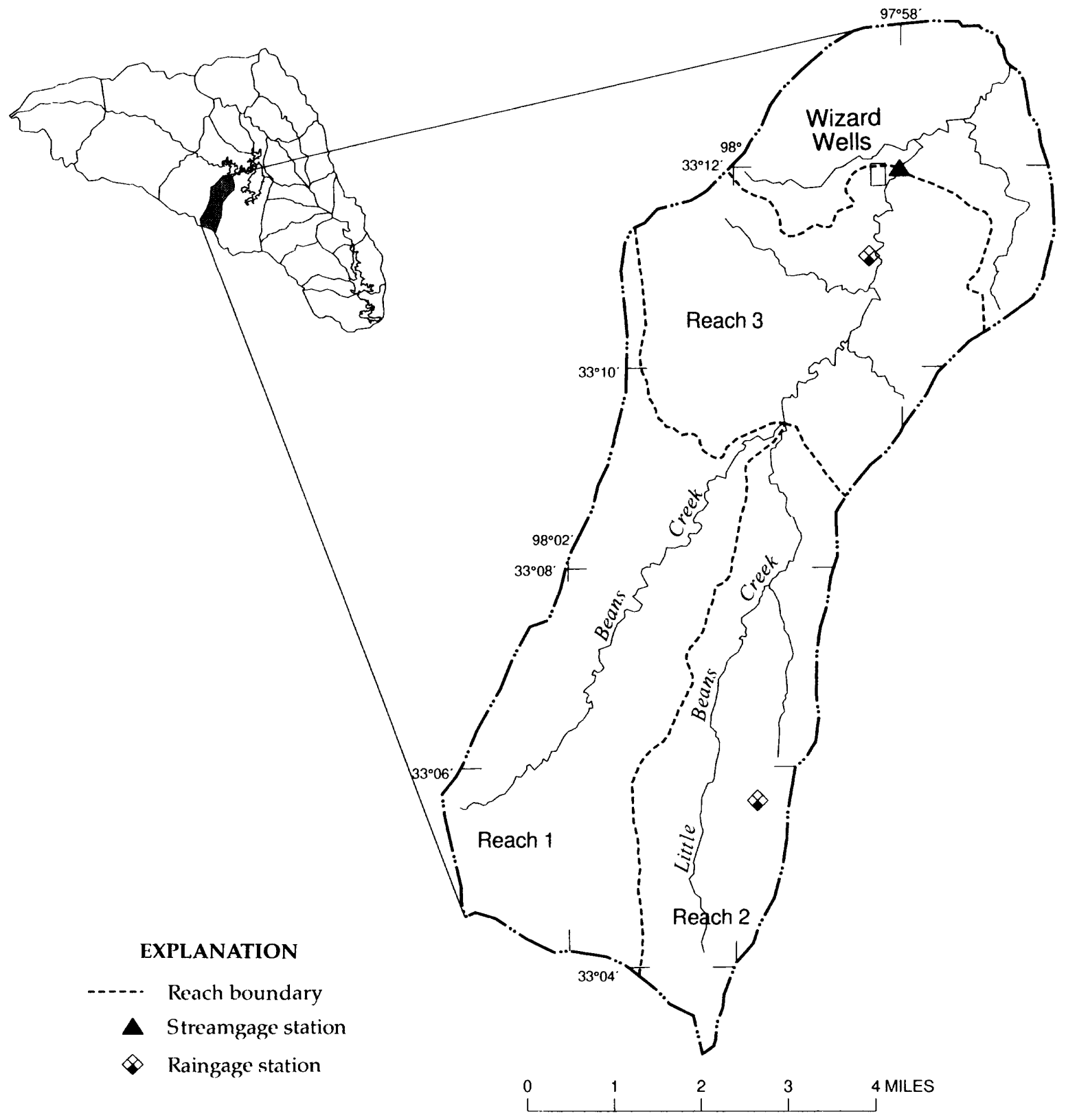

Figure 3. Data-collection network for the Beans Creek subbasin.

were installed during February to September 1992. Each streamgage station also included telephone communication equipment for remote data access. The streamgages were classified as partial-record gages and measured only stage above an index elevation. As a result, no base-flow data were recorded. Because the objective of this study was to simulate storm peaks and storm volumes, the assumption was that the partialrecord streangages would provide adequate data. Dis- charge rating tables were developed for each streamgage station using a water-surfacc-profile (WSPRO) model (Shearman, 1990). The theoretical rating tables were refined when a few direct discharge measurements were available. An effort was made to make more direct flood measurements, but because of a small number of large floods, the short duration of runoff, and the occurrence of flood peaks in the late evening and early morning, few flood measurements 


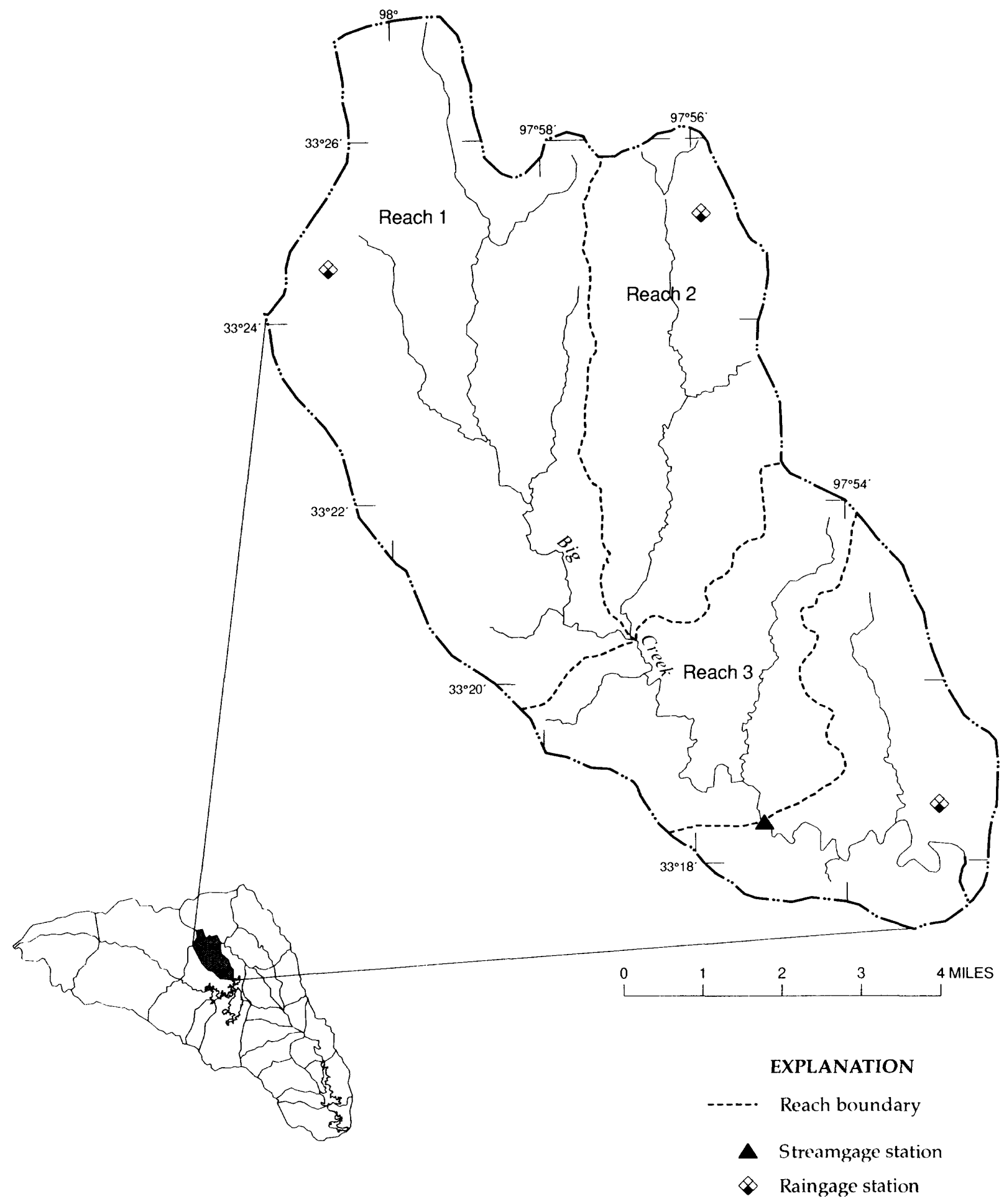

Figure 4. Data-collection network for the Big Creek subbasin. 


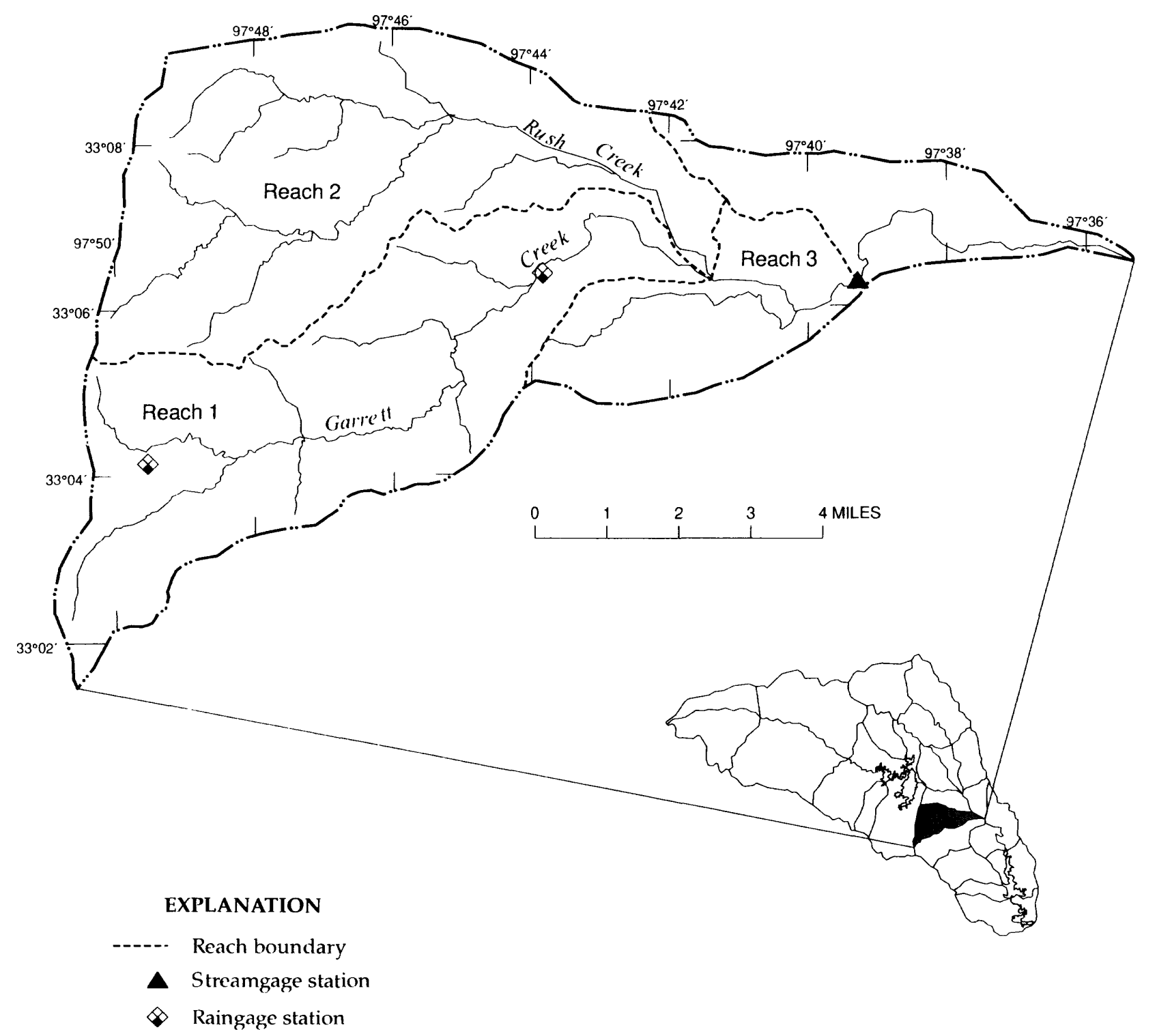

Figure 5. Data-collection network for the Garrett Creek subbasin.

were made during the study period. No flood measurements were available to refine the rating table for Big Creek. Continuous channel modification at Salı Creek during the study period required repeated shifting of the initial rating table. Rainfall was measured with a network of 10 tipping-bucket raingage stations (installed and operated by the cooperator) in the 5 gaged subbasins with 1 raingage for about every 25 $\mathrm{mi}^{2}$. The raingage network was supplemented by two to four daily observer stations in each subbasin. Some rainfall data werc lost because of instrumentation failure due to lightning strikes during the study period. These data were estimated using the rainfall totals measured at the nearby observer stations. Locations of the raingage and streamgage stations for each subbasin are shown in figures 3-7. Storm-runoff and rainfall data used in this report were collecled from October 1 , 1992, to September 30, 1994. Daily pan evaporation data measured at Lake Benbrook, about 15 miles (mi) south of Lake Worth, were used as representative data for the study area.

\section{Acknowledgments}

David Marshall, Alice Godbey, Louis Vernault, Steve Seija, Boyd Miller, Dale White, and Glenn 


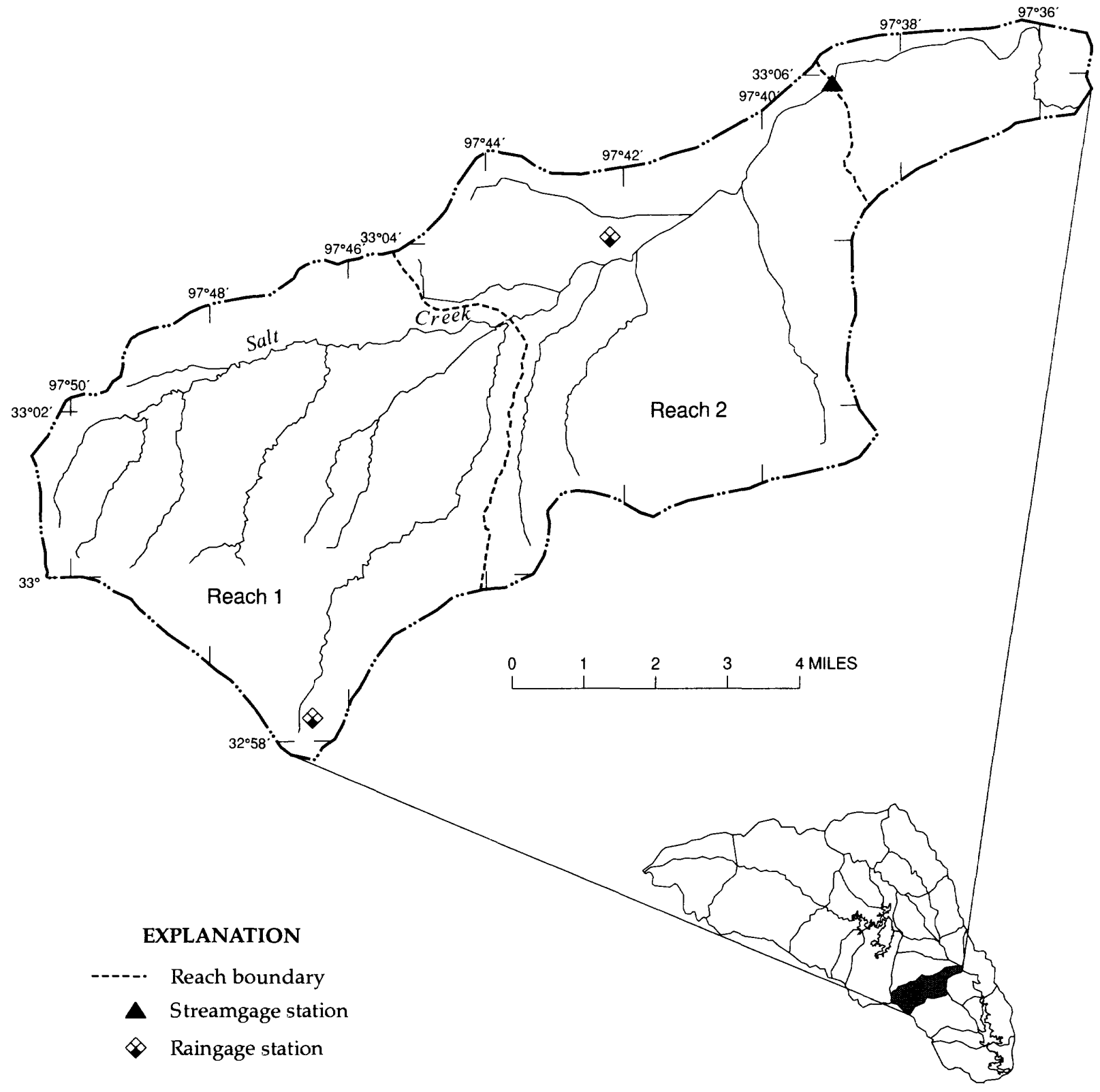

Figure 6. Data-collection network for the Salt Creek subbasin.

Sanderson of the Tarrant County Water Control and Improvement District No. 1 assisted with data collection, parameter estimation, and model development. Also, several residents in the study area measured and recorded daily precipitation. Charles Wood, David Tudor, Daryl Pinion, Bradley Mansfield, Jeffrey Sandlin, Clyde Schoultz, Ralph Ollman, Vernon Hastings, Martin Danz, Glenn Rivers, and Jack Benton of the U.S. Geological Survey helped in the installation, operation, and maintenance of the five streamgage stations.

\section{SIMULATION OF STORM PEAKS AND STORM VOLUMES}

To simulate storm peaks and storm volumes, a set of process-related model parameters was determined from calibration of data collected from the Beans Creek 


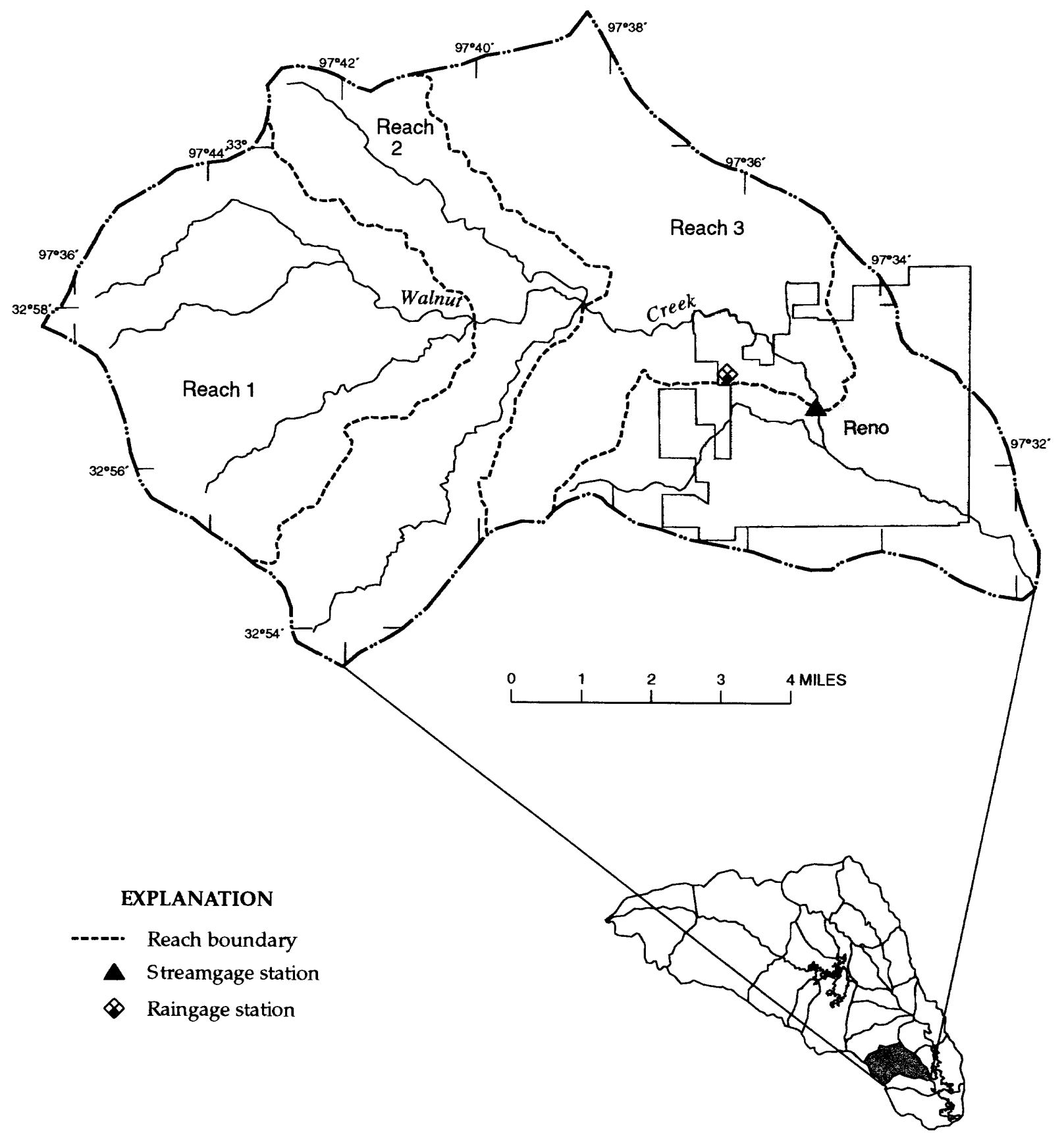

Figure 7. Data-collection network for the Walnut Creek subbasin.

and Walnut Creek subbasins from October 1, 1992, to September 30, 1993 (water year 1993). The parameter set was tested temporally on the Beans Creek and Walnut Creek subbasins using the data from October 1, 1993, to September 30, 1994 (water year 1994), and spatially on the Big Creek, Garrett Creek, and Salt Creek subbasins using data collected during the entire 24-month study period. The temporal and spatial testing provided a level of confidence when transferring the parameters to ungaged subbasins. An error analysis was done to identify sources of error that are not explained by the simulation model. A sensitivity analysis was done to identify which parameters had the greatest effect on simulation results. The parameters 
were revised on the basis of the results of the error and sensitivity analyses.

\section{Model Calibration and Testing}

The HSPF model was calibrated using data for the Beans Creek and Walnut Creek subbasins collected from October 1, 1992, to September 30, 1993 (water year 1993). Initial estimates for the 20 process-related parameters were (1) based on the physical properties of soil, land cover, and slope in the subbasins (Chow and others, 1988); (2) assigned the default values listed in table 1; or (3) taken from a previous study (Dinicola, 1990). For each land segment, the default values were used as the estimates for the parameters AGWETP, BASETP, DEEPFR, and KVARY because no data were available to calibrate the base-flow recession parameters. The estimates for the parameters INFEXP and INFILD also remained the default values because there was no justification to change the defaults. The 14 calibrated annual parameters are listed in table 5 (at end of report), the 3 calibrated monthly parameters are listed in table 6 (at end of report), and the 3 initial condition values are listed in table 7 (at end of report). Each parameter varied by soil group, land-cover group, or slope group corresponding to the physical process the parameter represents. For example, the parameters LZSN, INFILT, INTFW, and UZSN varied by soil group and represented the different storage and infiltration capacities of the soil, whereas the parameters CEPSC, LZETP, and NSUR varied by land-cover group and represented the different surface roughnesses, interception storages, and evapotranspiration potentials of the land-cover groups. The parameters LSUR and SLSUR varied by the watershed-slope group. The parameters AGWRC and IRC were assumed to be uniform for all land segments. The parameters INTFW, IRC, and NSUR were not varied monthly because iterative model simulations determined that the parameter values had little or no effect in explaining seasonal variations in runoff for this study area. Values of the annual parameters AGWRC, INFILT, INTFW, IRC, LSUR, LZSN, NSUR, and SLSUR values of the monthly parameters CEPSC, LZETP, and UZSN were adjusted during the calibration process using the software program HSPEXP (Lumb and others, 1994). The values for the initial conditions AGWS, LZS, and UZS were initially estimated from Dinicola (1990) and were revised during calibration. These values were varied by soil group.
A total of 55 storms were recorded in the 5 gaged subbasins from October 1, 1992, to September 30, 1994; the minimum was 6 storms for the Big Creek subbasin, and the maximum was 16 storms for the Walnut Creek subbasin. The calibrated parameter set (tables 56) was developed from 10 storms that occurred during water year 1993 in the Beans Creek and Walnut Creek subbasins. The remaining 45 storms were used to test the parameters temporally and spatially to assess the transferability of the parameter set to ungaged subbasins.

The measured and simulated times of peak, storm peaks, storm volumes, and errors for the calibration and testing simulations are listed in table 8 (at end of report). The simulated times of peak are within 3 hours of the measured times of peak for the 3 storms for the Beans Creek subbasin and the 7 storms for the Walnut Creek subbasin during water year 1993. The errors for storm peaks range from -60.8 to 214 percent, and the errors for storm volumes range from -66.7 to 111 percent for the 10 storms that were used for calibration (table 8 ). The maximum simulated storm peak and storm volume during water year 1993 for the Beans Creek subbasin are greater than the maximum measured values, whereas the maximum simulated storm peak and storm volume for the Walnut Creek subbasin are less than the maximum measured values. Five of the 10 storm peaks and 6 of the 10 storm volumes have an absolute error of less than 50 percent. The best agreement between the 10 measured and simulated hydrographs used for the model calibration is shown in figure 8 for Walnut Creek at Reno during September 13-14, 1993.

Five storms for the Beans Creek subbasin and 9 storms for the Walnut Creek subbasin during water year 1994 were used to test the parameters temporally. The simulated times of peak are within 3 hours of the measured times of peak for 13 of the 14 storms (table 8 ). The errors for storm peaks range from -98.6 to 416 percent, and the errors for storm volumes range from -87.8 to 258 percent.

Six storms for the Big Creek, 12 storms for the Garrett Creek, and 13 storms for the Salt Creek subbasins during both water years were used to test the parameters spatially (table 8 ). The simulated times of peak are within 3 hours of the measured time for 19 of the 31 storms. The errors for storm peaks range from -99.6 to 1,000 percent, and the errors for storm volumes range from -98.7 to 786 percent. For the testing period, 6 of the 8 maximum storm peaks of the water year for each subbasin and 4 of the 8 maximum storm volumes 

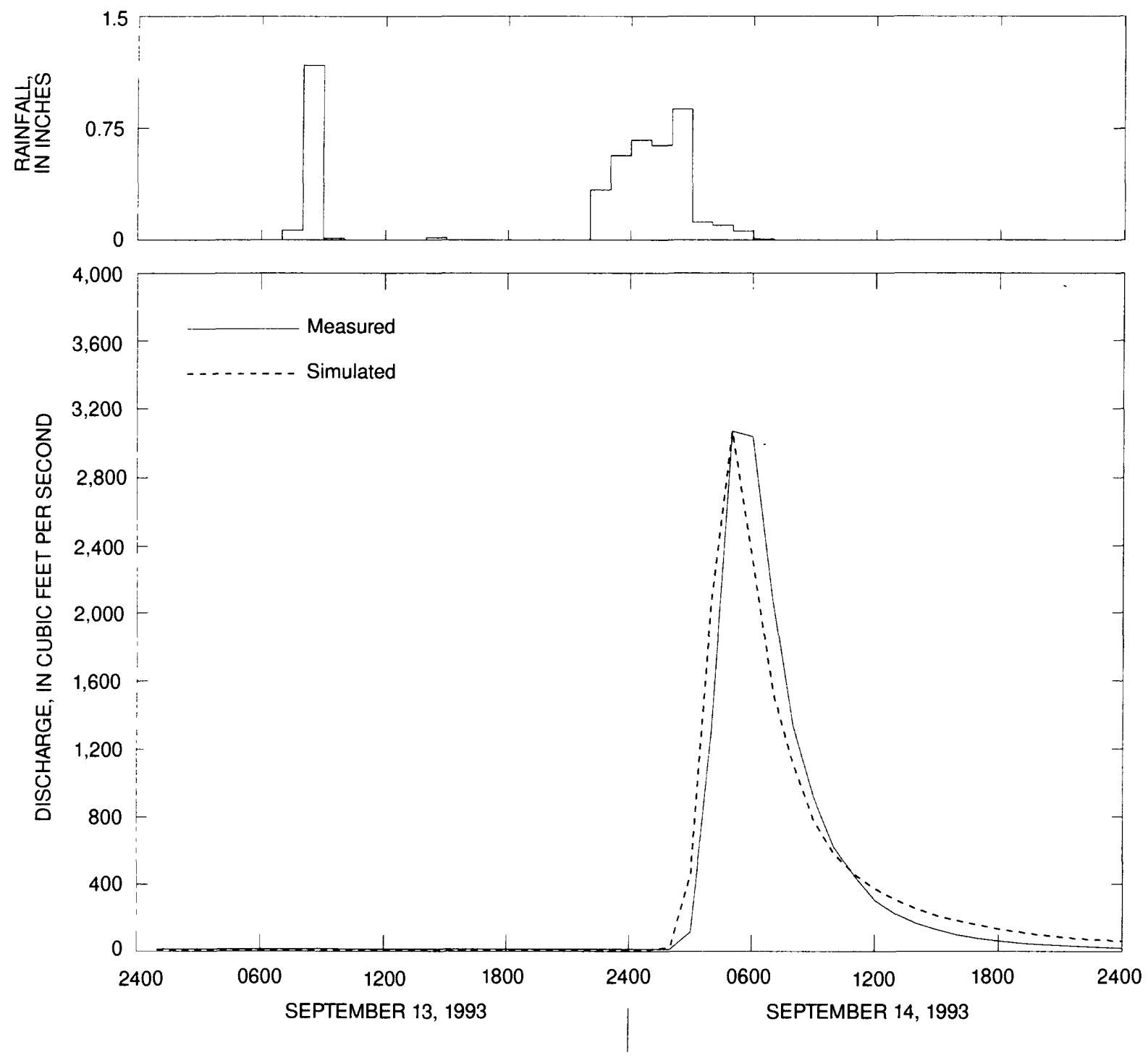

TIME, IN HOURS

Figure 8. Measured and simulated hydrographs for Walnut Creek at Reno, Texas, September 13-14, 1993.

of the water year for each subbasin have a simulated value higher than the measured value. Only 10 of the 45 storms used for testing have an absolute error of less than 50 percent for both storm peaks and storm volumes. One of the best agreements between measured and simulated hydrographs used for testing is for Garrett Creek near Paradise during May 11-13, 1994 (fig. 9).

The measured times of peak and the simulated times of peak for the 55 storms are shown in figure 10. The difference between the simulated and measured time of peak is within 3 hours for most storms; there was a tendency for the simulated peak to occur before the measured peak.

The measured storm peaks and the simulated storm peaks for the 55 storms are shown in figure 11 . There is a fairly symmetric spread of simulated peaks greater than about 70 cubic feet per second $\left(\mathrm{ft}^{3} / \mathrm{s}\right)$ about the match line; and there is a cluster of simulated storm peaks less than about $70 \mathrm{ft}^{3} / \mathrm{s}$ that underestimates measured storm peaks in the $100-$ to $2,000-\mathrm{ft}^{3} / \mathrm{s}$ range. 

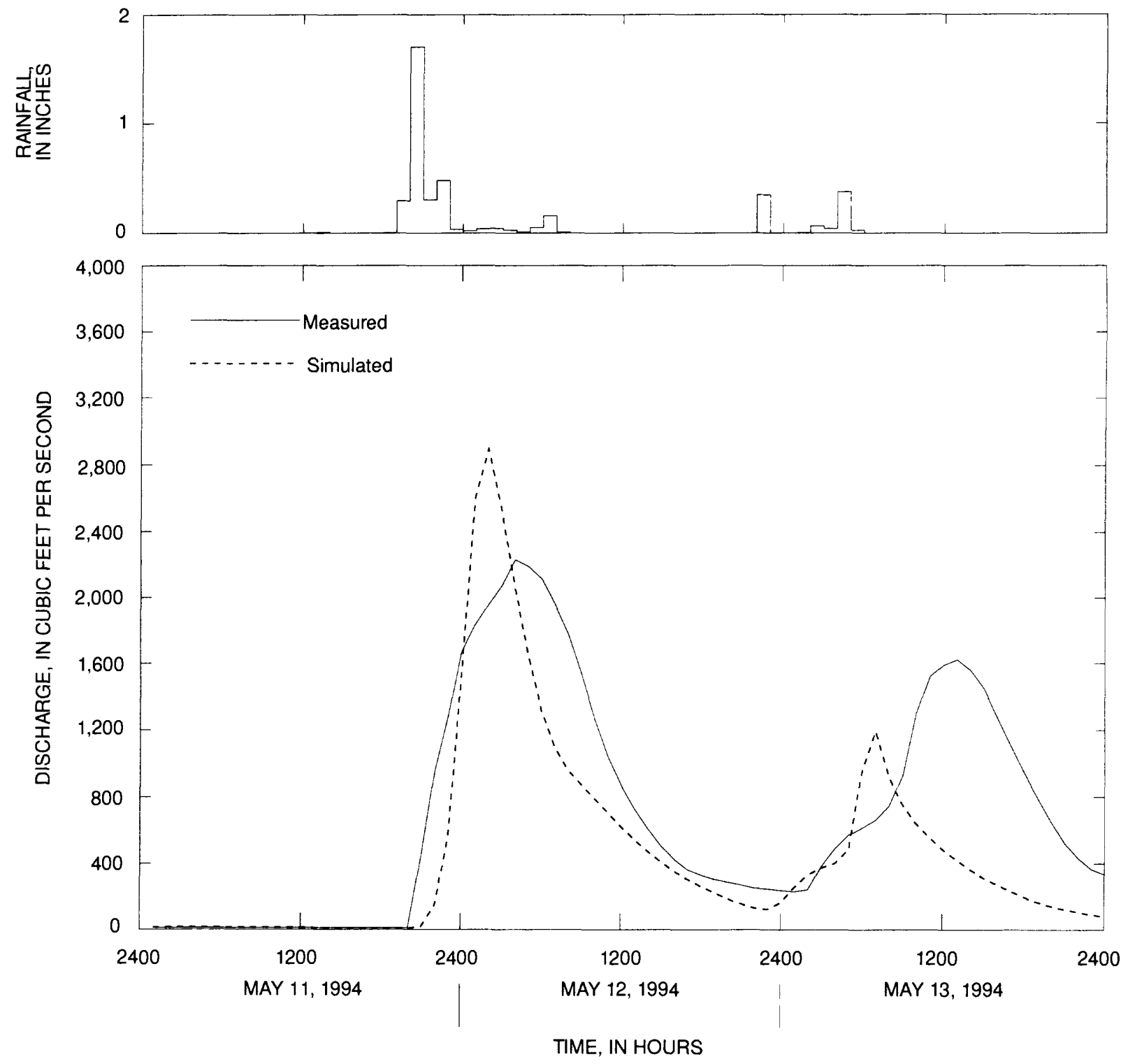

Figure 9. Measured and simulated hydrographs for Garrett Creek near Paradise, Texas, May 11-13, 1994.

The measured storm volumes and the simulated storm volumes for the 55 storms are shown in figure 12 . Overall, there is a fairly symmetric spread of simulated volumes greater than about 0.02 in. about the match line; and there is a cluster of simulated storm volumes less than $0.02 \mathrm{in}$. that underestimates measured storm volumes in a range from about 0.04 to $0.30 \mathrm{in}$.

The mean absolute error and bias for the measured and simulated storm peaks and storm volumes for each water year for the five gaged subbasins are listed in table 9 (at end of report). Mean absolute error is the average of the absolute values of all storm errors; bias is the average of all storm errors. A small bias occurs when positive errors and negative errors are almost equal. For the calibration data from water year 1993, the mean absolute error and bias for the three storm peaks for the Beans Creek subbasin are 48.0 and 6.7 percent and for the seven storm peaks for the Walnut Creek subbasin are 63.2 and 6.9 percent. The mean absolute error and bias for storm volumes are 46.6 and -9.9 percent for the three storm peaks for the Beans Creek subbasin and are 34.4 and -2.2 percent for the seven storm volumes for the Walnut Creek subbasin. For the temporal-testing data from water year 1994, the mean 


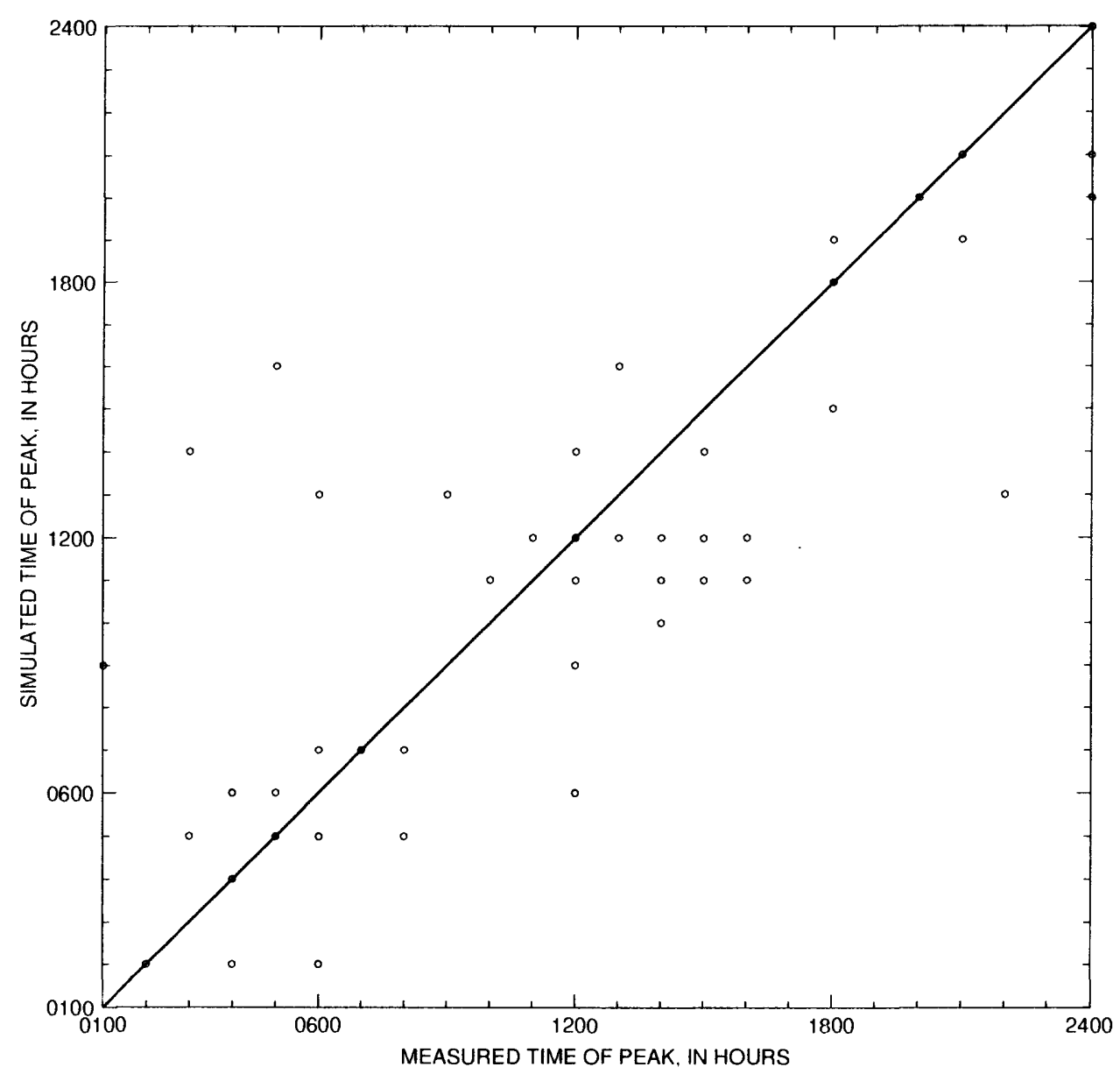

Figure 10. Measured times of peak and simulated times of peak using calibrated parameters.

absolute error and bias are 153 and 85.2 percent for the Beans Creek subbasin and are 81.0 and -21.9 percent for the Walnut Creek subbasin. The results are similar for storm volumes; the mean absolute error and bias are 132 and 68.6 percent for the Beans Creek subbasin and are 63.7 and -8.0 percent for the Walnut Creek subbasin. For the spatial-testing data from the other three subbasins tested, the mean absolute errors for storm peaks range from 68.3 to 470 percent, and the biases range from -47.2 to 401 percent. The mean absolute errors for storm volumes range from 58.7 to 416 percent, and biases range from -52.4 to 416 percent.

The mean absolute errors in storm volumes are less than the errors in storm peaks for every subbasin except Big Creck (lable 9). The errors for testing simulations generally are larger than the errors for calibration simulations. The mean absolute errors also generally increase from water year 1993 to water year 1994 for the five subbasins.
The monthly distribution of errors for storm peaks and storm volumes for the 24-month study period is listed in table 10 (at end of report). Forty of the 55 storms occurred in 4 months - February, May, September, and October. The remaining 15 storms are distributed through March, April, Junc, August, November, and December. No storms occurred in January and July. The distribution of errors was relatively even for simulating storm peaks, but there scemed to be a bias for undersimulating storm volumes.

\section{Error Analysis}

The types of error from the model calibration and testing can be classified as measurement errors or systematic errors. Measurement errors are introduced as a result of missing data and inaccurate rating tables of stage and discharge. Rainfall data are missing for several raingage stations during January through 


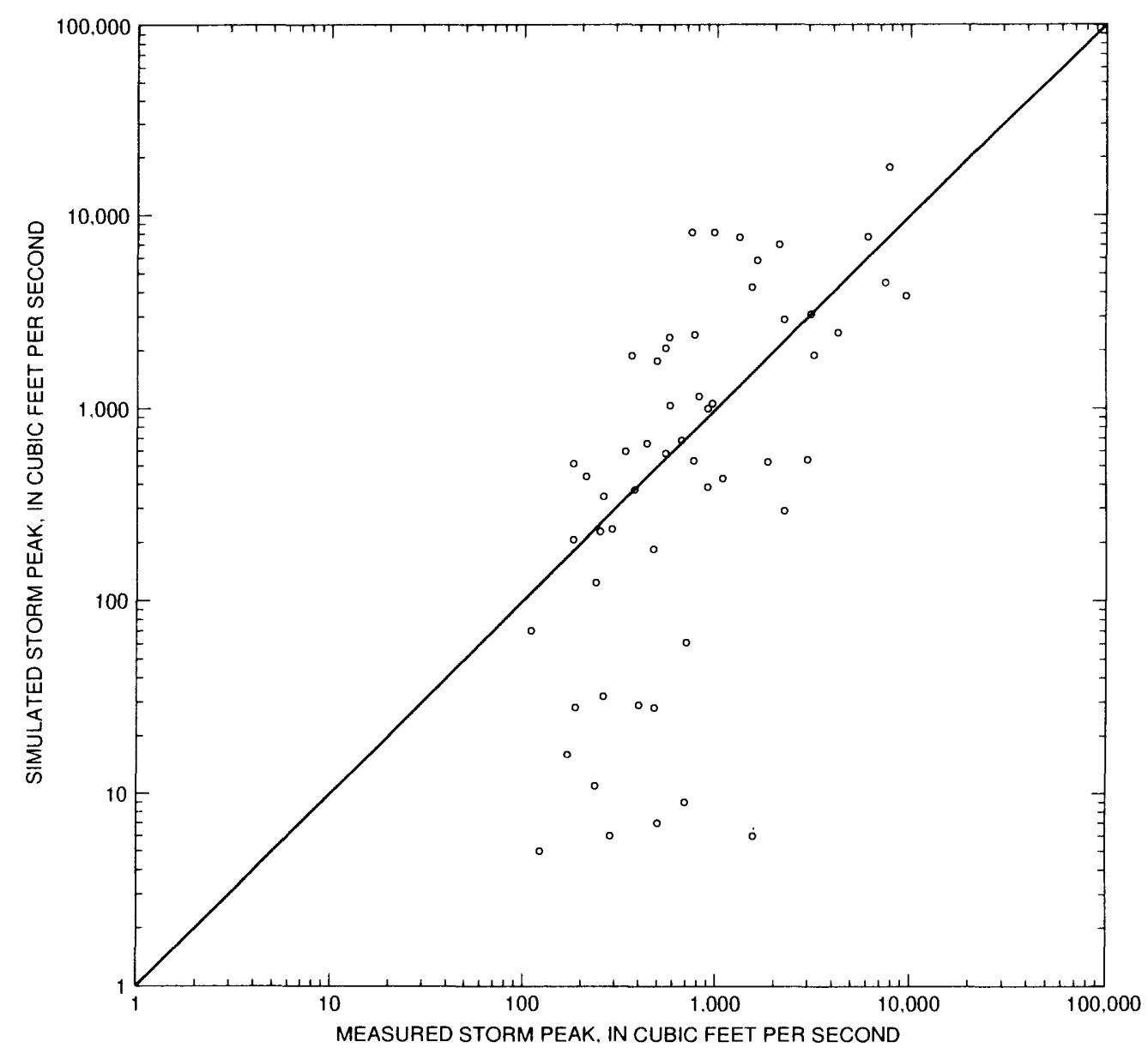

Figure 11. Measured storm peaks and simulated storm peaks using calibrated parameters.

March 1993 and had to be estimated from daily observer data. The two streamgage stations with the highest simulation errors, Big Creek and Salt Creek (table 9), also had the least accurate rating tables which result in inaccurate discharge records. The spatial variability of rainfall might not be represented adequately with the existing raingage network of two to three points in each subbasin.

Systematic errors are associated with the inability of the simulation model to represent the physical processes of runoff. These errors are represented in the model parameters and model equations. The wide variation in measured rainfall compared to measured storm volume indicates the seasonal differences in runoff (fig. 13). A total of 4.20 in. of rainfall produced 1.56 in. of runoff in May on Walnut Creek, whereas 4.84 in. of rainfall produced only 0.36 in. of runoff in September. The model parameters and model equations need to account for these variations. On average, 11 storms were measured among 5 gaged subbasins during the 24 month study period, ranging from 6 at Big Creek to 16 at Walnut Creek. Eleven is a very small number of storms when calibrating the model to account for a full range of storm volumes, seasons, and antecedent soilmoisture conditions. Another limitation of this study involved using flood-hydrograph streamgage stations with a continuous-simulation model, which provided no data to calibrate the parameters related to base flow. The pervious land segments used in this model might not represent adequately all the different hydrologic response units of the study area. Also, some uncertainty exists in the values of FTABLES for the reach volume and the corresponding discharge, which seems to be true for the Big Creek and Salt Creek subbasins.

The measurement and systematic errors account for some of the error and bias of the simulated storm peaks and storm volumes. However, from the results listed in tables 8-9 and shown in figures $10-12$, the 


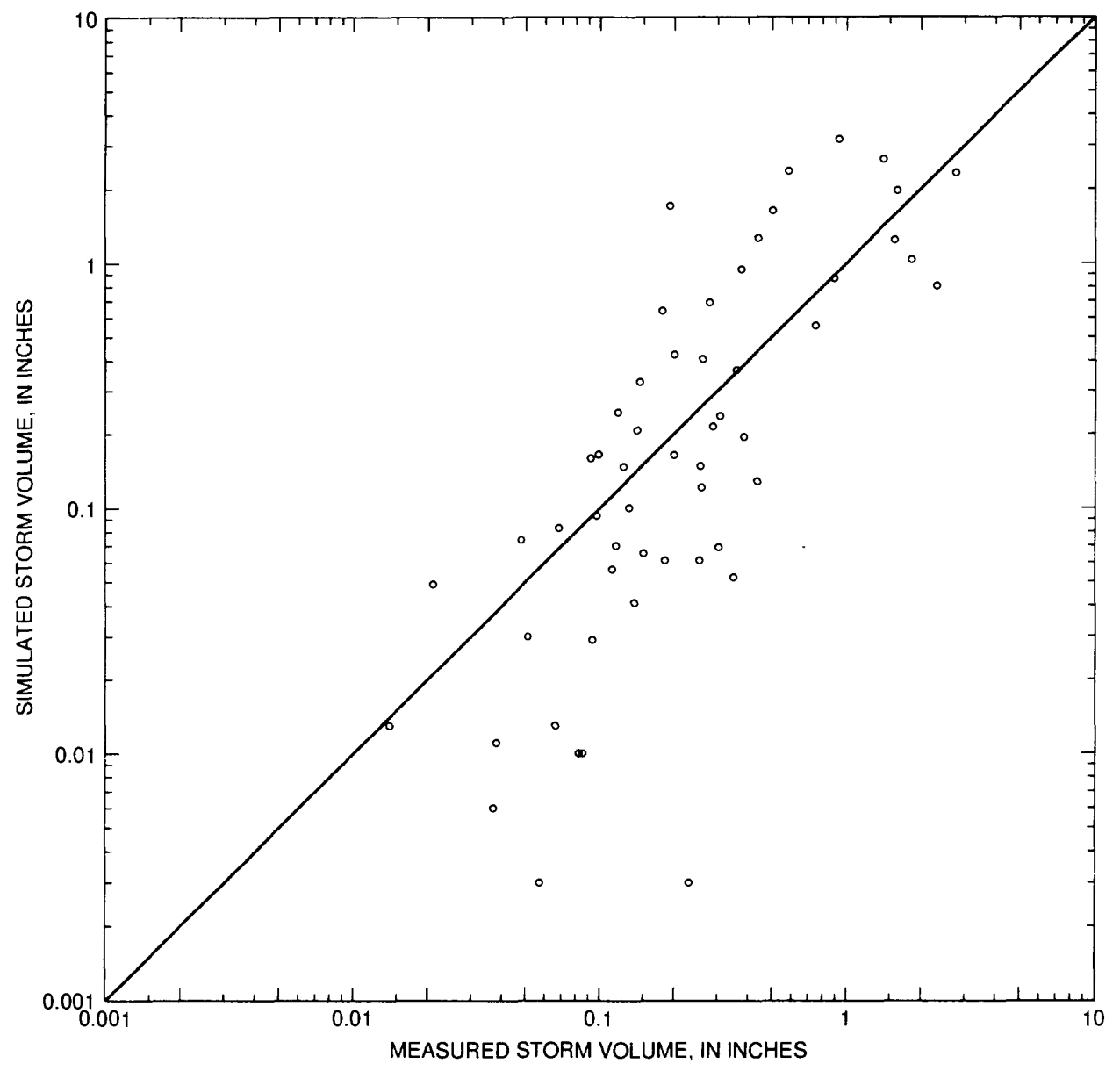

Figure 12. Measured storm volumes and simulated storm volumes using calibrated parameters.

calibrated parameter set does not adequately simulate the storm peaks and storm volumes. There could be a seasonal bias for simulating storm volumes based on the monthly distribution of simulation errors presented in table 10. Also, the errors seem to increase from water year 1993 to water year 1994 (table 9). Additional information on the sensitivity of each parameter might provide some insight into which parameters might be adjusted to provide better calibration and testing results.

\section{Sensitivity Analysis}

A sensitivity analysis was done on selected parameters on the Walnut Creek subbasin to determine what effect a change in a parameter value has on the largest storm peak and the total storm volume for the 24 months. The simulation was done using data from 10 of the 16 storms for Walnut Creek. A maximum of 10 storms can be used for calibration by the expert system of HSPEXP (Lumb and others, 1994). The largest simulated peak discharge is $15,400 \mathrm{ft}^{3} / \mathrm{s}$, and the total simulated storm volume is 4.57 in., using the calibrated model parameters for the entire 24 months. The change in simulated peak discharge from $17,800 \mathrm{ft}^{3} / \mathrm{s}$ listed in table 8, using the calibrated model parameters for water year 1993 , to $15,400 \mathrm{ft}^{3} / \mathrm{s}$, using the calibrated model parameters for the 24 months, represents the sensitivity of storm peaks to the change in the initial conditions (AGWS, LZS, and UZS values) assumed for calibration (table 7) to the simulated values at the end of water year 1993.

Each parameter was modified to represent a reasonable change. The changes in model results relative to a change in the parameter value are listed in table 11 (at end of report). The parameters INFILT, LZSN, and UZSN have the most effect on both storm 


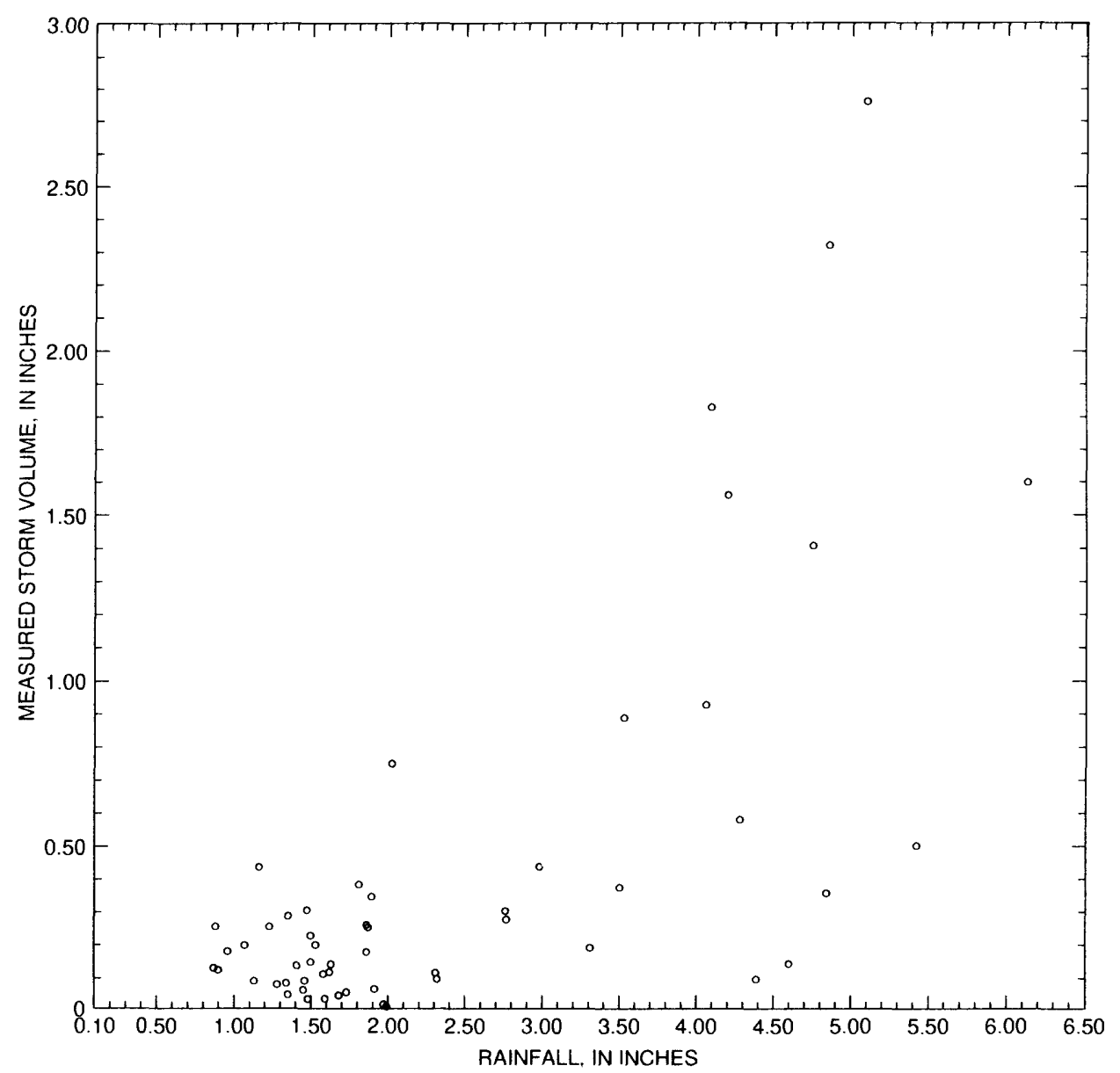

Figure 13. Rainfall and measured storm volume.

peaks and storm volumes combined; the parameters DISCH, LSUR, NSUR, SLSUR, and VOL primarily affect the timing and magnitude of the storm peaks with relatively less effect on the storm volumes. None of these parameters affected the timing of the largest peak, but a few of the smaller storm peaks were affected. Also, the parameters AGWS, LZS, and UZS represent the initial conditions at the start of the simulation and did not have an effect on storm peaks that occurred more than 6 months into a simulation, but did have an effect on the storm peaks and storm volumes that occurred early in a simulation. Changing the 11 parameters noted above produced the largest change in model results.

\section{Model Recalibration and Testing}

A new process-related parameter set was developed from the recalibration of the Beans Creek and
Walnut Creek subbasins from October 1, 1992, to September 30, 1994, using information derived from the error analysis and the sensitivity analysis, and was tested on the data from Big Creck, Garrett Creek, and Salt Creek. The model was run for the entire period of record to provide additional storms for calibration. Some values of parameters INFILT, INTFW, LZETP, and LZSN were increased and some values of UZSN were decreased to decrease the magnitude of the storm peaks and storm volumes. Some values of parameters LSUR and NSUR were increased, whereas some values of SLSUR were decreased. The values of the parameter CEPSC were not modified. The values of parameters AGWRC and IRC were decreased to steepen the ground-water and interflow recession rates. The values of parameter BASETP were modified from the default value of zero (table 1 ) to 0.1 to allow available potential evaporation to be satisfied from base flow. 
The parameters KVARY, INFEXP, INFILD, DEEPFR, and AGWETP retained the default values listed in table 1. The recalibrated annual parameters are listed in table 12 (at end of report); the 3 recalibrated monthly parameters are listed in table 13 (at end of report); and the 3 initial condition values are listed in table 14 (at end of report).

The FTABLE volumes from table 4 were increased by 25 percent for the Big Creek, Garrett Creek, and Salt Creek subbasins to provide more storage in the reaches for each subbasin to decrease the magnitude of the storm peaks. The initial values for AGWS, LZS, and UZS for water year 1994 (table 14) were from the simulation output from the end of water year 1993.

Data from the 8 storms for the Beans Creek subbasin and the 16 storms for the Walnut Creek subbasin during water years 1993 and 1994 were used to recalibrate HSPF. The remaining 31 storms for the other 3 subbasins were used to test the recalibrated parameters. The measured and simulated times of peak, storm peaks, storm volumes. and errors using recalibrated parameters for the five subbasins are listed in table 15 (at end of report).

The difference between the measured and simulated times of peak, using the recalibrated parameters, is within 3 hours for 23 of the 24 storms for the Beans Creek and Walnut Creek subbasins (table 15). The errors for the storm peaks range from -99.9 to 312 percent using the recalibrated parameters (table 15 ), compared to -98.6 to 416 percent using the calibrated parameters (table 8 ). The errors for the storm volumes using the recalibrated parameters range from -98.8 to 203 percent (table 15 ), compared to -87.8 to 258 percent using the calibrated parameters (table 8 ). Although the ranges of errors were decreased using the recalibrated parameters, the number of storms with absolute errors less than 50 percent did not improve. Nine storm peaks and 10 storm volumes of the 24 storms using the recalibrated parameters have errors less than 50 percent (table 15), compared to 9 storm peaks and 9 storm volumes of the 24 storms using the calibrated parameters (table 8). The improvement in the simulated hydrograph for Beans Creek on February 14-16, 1993, using the recalibrated parameters compared to the simulated hydrograph using the calibrated parameters, is shown in figure 14. The error of the storm peak improved from 82.1 percent (table 8) to -18.4 percent (table 15), and the error of the storm volume improved from 55.0 percent (table 8 ) to -15.3 percent (table 15).

The recalibrated parameters were tested for 6 storms for Big Creek, 12 storms for Garrett Creek, and 13 storms for Salt Creek during water years 1993 and 1994. Twenty-two of the 31 simulated times of peak are within 3 hours. Most of the nine storms for which the simulated time of peak differs by more than 3 hours from the measured time of peak correspond to the storms for which little or no runoff was simulated. The errors for the storm peaks using the recalibrated parameters range from -99.9 to 582 percent (table 15), compared to -99.6 to 1,000 percent using the calibrated parameters (table 8 ). The errors for storm volumes using the recalibrated parameters range from -99.6 to 306 percent (table 15), compared to -98.7 to 786 percent using the calibrated parameters (table 8). Six storm peaks and 7 storm volumes for the 31 storms using the recalibrated parameters have absolute errors less than 50 percent (table 15), compared to 10 storm peaks and 11 storm volumes for the 31 storms using the calibrated parameters (table 8).

Seven of the 10 maximum simulated storm peaks and 5 of the 10 maximum storm volumes for each water year for the 5 gaged subbasins exceed the measured values (table 15). These results, using the recalibrated parameters, are the same as the results using the calibrated parameters (table 8 ).

The measured and simulated hydrographs for Big Creek near Chico during October 19-20, 1993, are shown in figure 15 . There is relatively good agreement between simulated and measured storm peaks using the recalibrated parameters, but the storm volume is overestimated.

Measured times of peak and simulated times of peak using the recalibrated parameters for the 55 storms are shown in figure 16. The time of peak either remained unchanged or was delayed 1 hour from the times shown in figure 10 for most of the 55 storms. The storms with the largest differences generally were the storms for which little or no simulated runoff was generated.

Measured storm peaks and simulated storm peaks for the 55 storms using the recalibrated parameters are shown in figure 17. The distribution of data about the match line is very similar to the distribution in figure 11. The same 11 simulated storm peaks of less than about $70 \mathrm{ft}^{3} / \mathrm{s}$ from figure 11 are less than the corresponding measured storm peaks. 

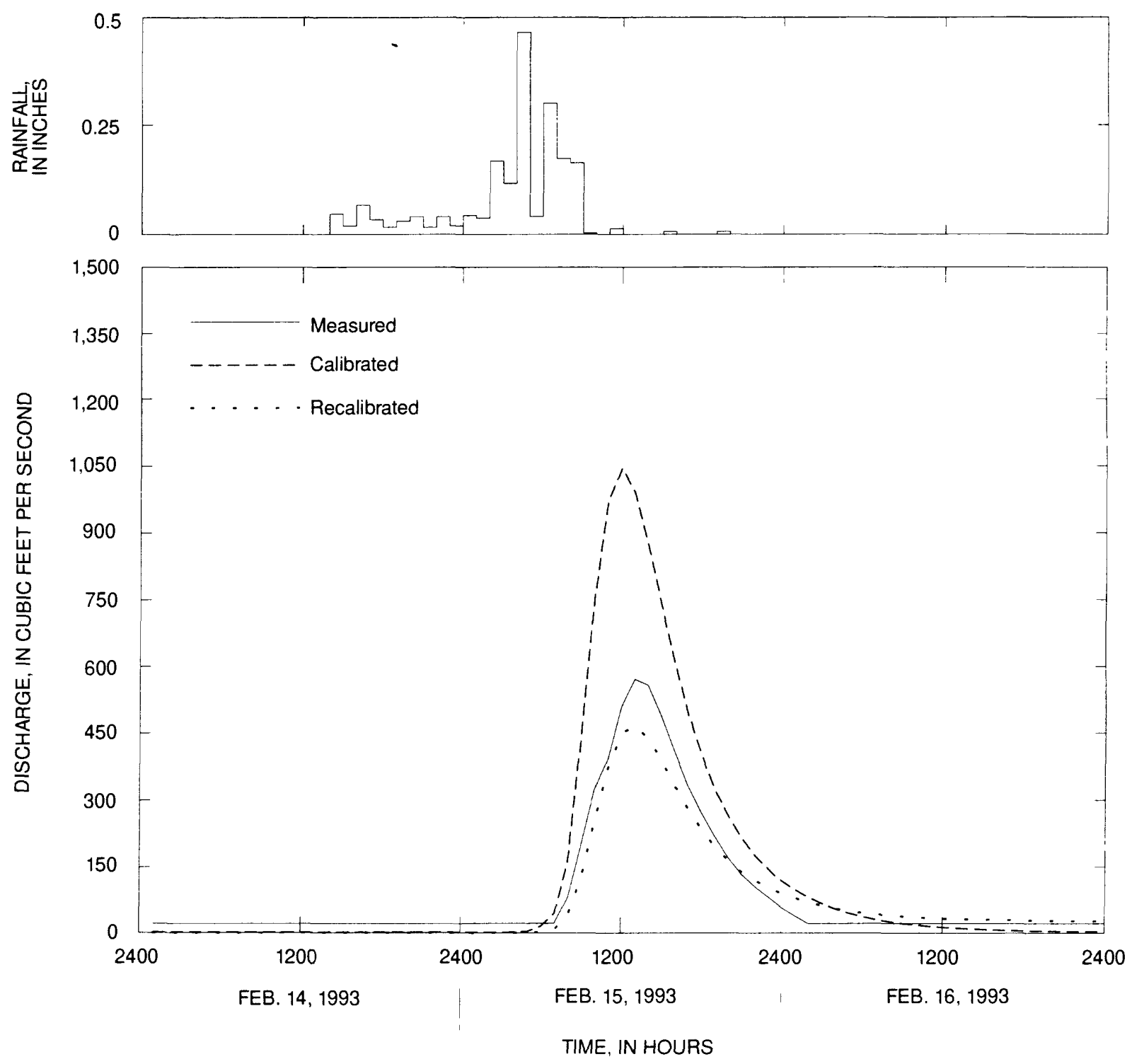

Figure 14. Measured and simulated hydrographs for Beans Creek at Wizard Wells, Texas, February 14-16, 1993.

Measured storm volumes and simulated storm volumes for the 55 storms using the recalibrated parameters are shown in figure 18. The distribution of data about the match line is very similar to the distribution in figure 12. Ten of the 55 simulated storm volumes are less than 0.02 in. and are clustered apart from the rest of the data, which is similar to the simulated storm peaks (fig. 17) where increased infiltration, storage, and evaporation, as represented by the recalibrated parameters, generated little or no simulated runoff for some storms.

The mean absolute errors and biases of storm peaks and storm volumes for each water year using the recalibrated parameters for the five gaged subbasins are listed in table 16 (at end of report). The mean absolute errors for each subbasin for storm peaks range from 47.1 to 297 percent using the recalibrated parameters compared to 48.0 to 470 percent using the calibrated parameters (table 9). The mean absolute errors for each subbasin for storm volumes range from 27.6 to 193 percent using the recalibrated parameters compared to 34.4 to 416 percent using the calibrated parameters (table 9 ). The biases for each subbasin for storm peaks range from -85.4 to 202 percent using the recalibrated parameters compared to -47.2 to 401 percent using the calibrated 


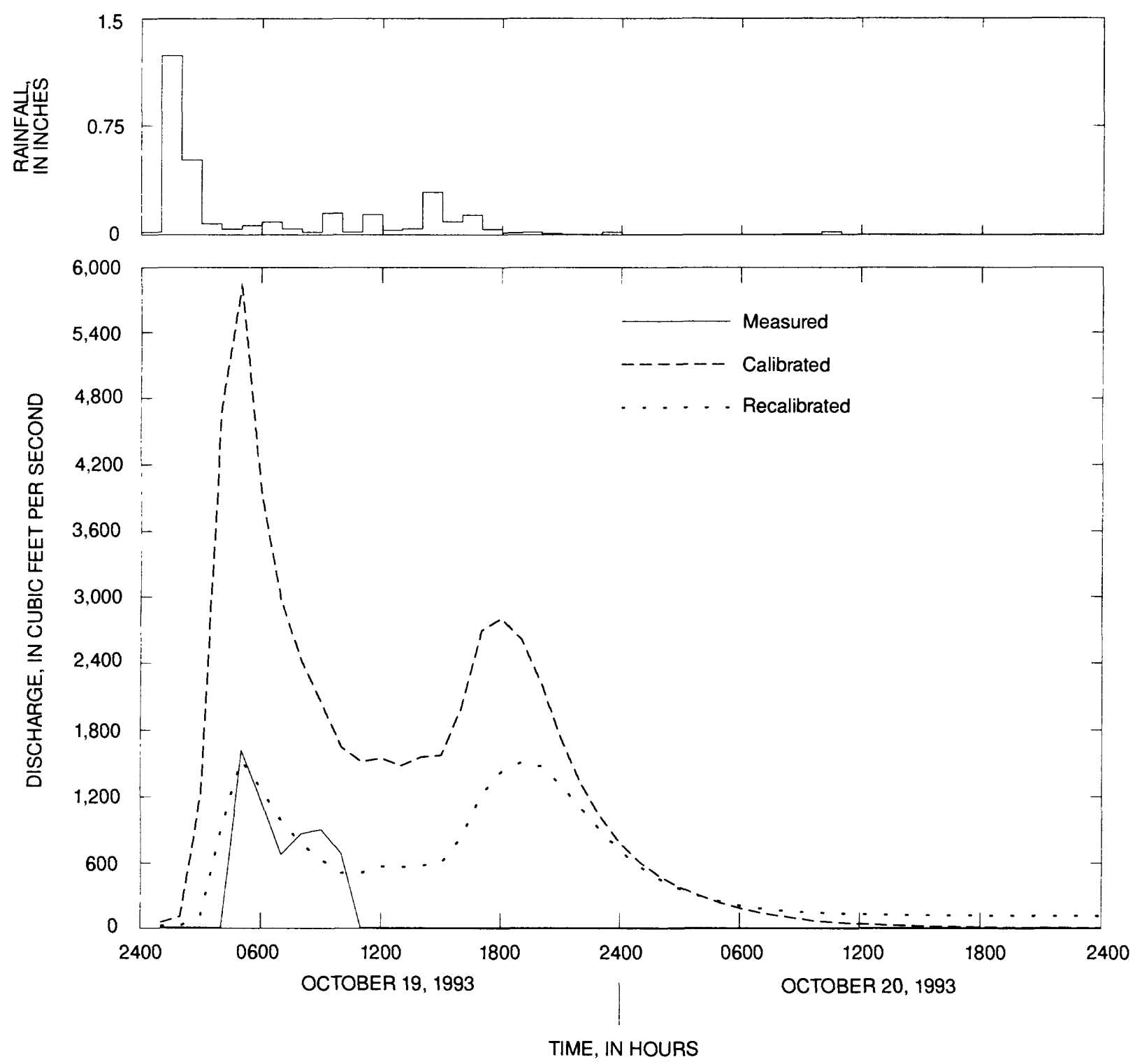

Figure 15. Measured and simulated hydrographs for Big Creek near Chico, Texas, October 19-20, 1993.

parameters (table 9). The biases for each subbasin for storm volumes range from -75.6 to 114 percent using the recalibrated parameters compared to -52.4 to 416 percent using the calibrated parameters (table 9). The errors for the five gaged subbasins generally decreased using the recalibrated parameters.

The mean absolute errors and biases generally are less for the storm volumes than for the storm peaks using the recalibrated parameters (table 16), which is similar to the results of the initial calibration (table 9). In addition, the mean absolute error and bias using the recalibrated parameters (table 16) increases from water year 1993 to water year 1994 for fewer storm peaks and storm volumes than using the calibrated parameters (table 9).

The monthly distribution of errors for storm peaks and storm volumes for the 55 storms using the recalibrated parameters are listed in table 17 (at end of report). The monthly results are similar to the results using the calibrated parameters (table 10); however, the annual totals are somewhat reversed: the calibrated parameters tend more to undersimulate storm volumes, whereas the recalibrated parameters tend more to undersimulate the storm peaks. December is the only 


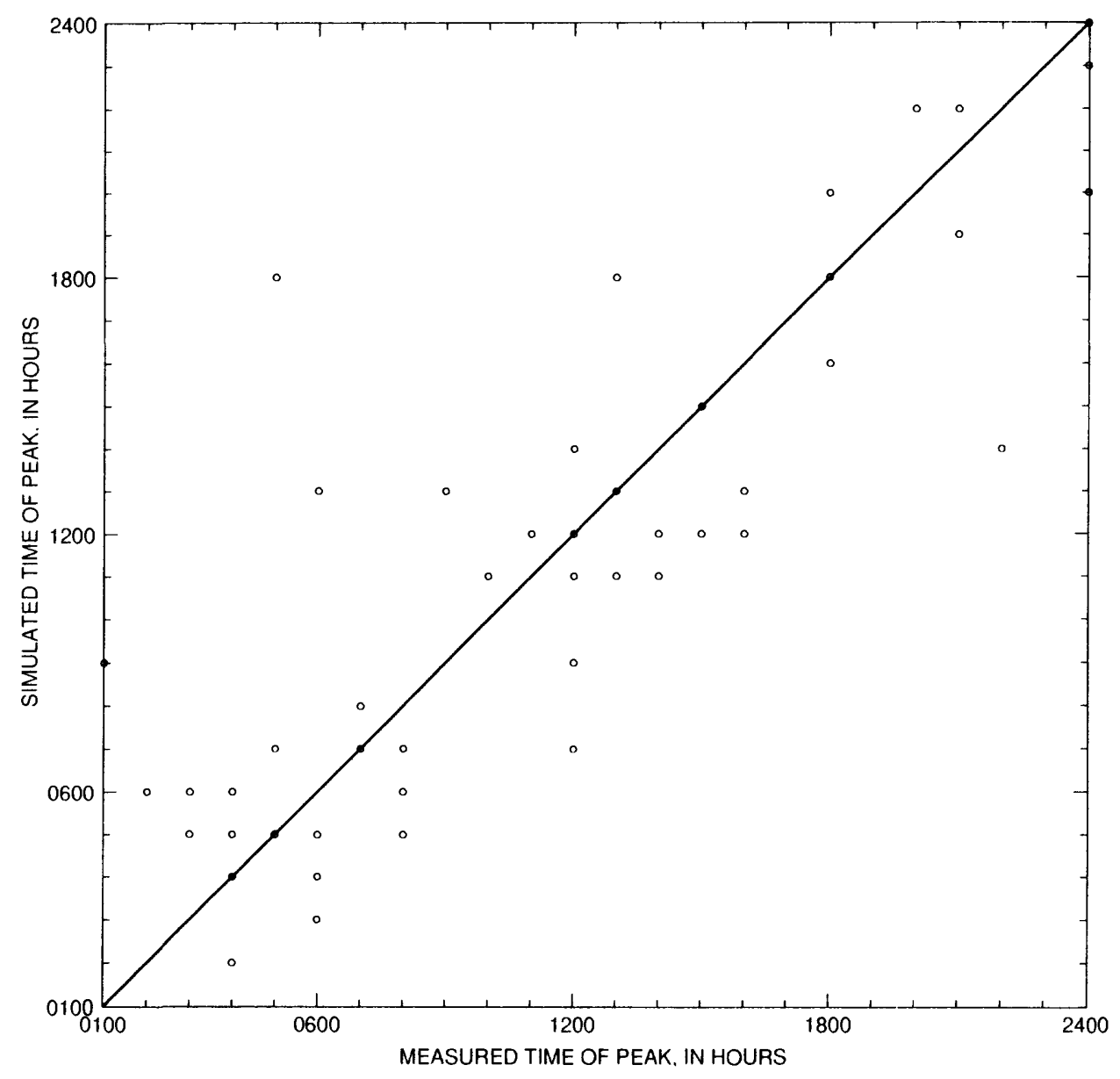

Figure 16. Measured times of peak and simulated times of peak using recalibrated parameters.

month that indicates a bias to oversimulating storm peaks and storm volumes using the recalibrated parameters. However. more storm data are needed to clearly indicate a monthly bias for simulating storm peaks and storm volumes for the other 11 months.

\section{Transfer of Model Parameters to Ungaged Subbasins}

The model produced better results for simulation of the larger storm peaks and storm volumes than for simulation of the smaller storm peaks and storm volumes, especially after an extended period of no runoff. However, only selected data for 55 storms at 5 subbasins during 24 months were used to calibrate and test the HSPF model parameters. A continuous-simulation model does provide a means to account for some variations in runoff generation compared to event-based models. The recalibrated process-related parameter set can be transferred to the other ungaged subbasins with the same range in error expected. The basin-related parameters will need to be computed for each ungaged subbasin.

On the basis of the results of this study, additional collection of storm-runoff data, improvement of discharge rating curves, and identification of additional sources of rainfall data could result in model parameters that account for the wide variations in runoff and reduce the range of expected error in model simulation. A longer period of record would provide a better representation of the combinations of storm size, season, and antecedent moisture conditions. The smaller storm peaks that occur during spring and summer might be the result of more widely scattered rainfall with nonuniform intensity. 


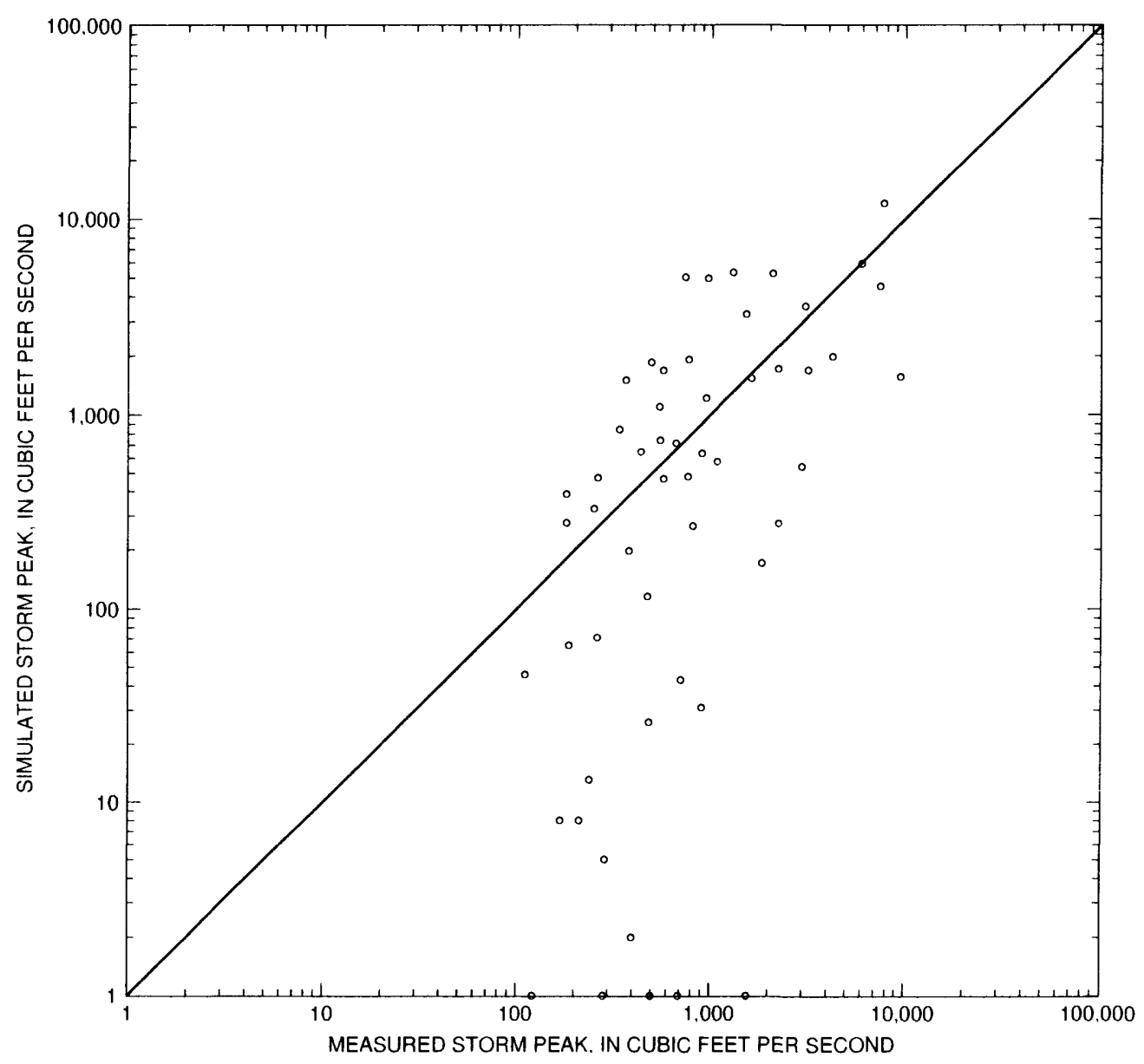

Figure 17. Measured storm peaks and simulated storm peaks using recalibrated parameters.

\section{SUMMARY}

The purpose of this study was to simulate storm peaks and storm volumes for selected subbasins of the West Fork Trinity River Basin upstream from Lake Worth northwest of Fort Worth, Texas. The simulated flows can be used as input to a channel-routing model that can be used to improve reservoir operation in the basin during floods.

A model parameter set for use with HSPF was developed to simulate storm peaks and storm volumes for ungaged subbasins from calibration and testing of five gaged subbasins. Rainfall and runoff data were collected from October 1, 1992, to September 30, 1994, with a total of 55 storms used in this study. Twelve different pervious land segments were defined for the study based on 2 groups of soil, 3 groups of land cover, and 2 groups of slope. Seventeen parameters were defined for each land segment.
The model was calibrated with data from 10 storms and tested temporally and spatially with data from the remaining 45 storms. The mean absolute errors for storm peaks for the five subbasins range from 48.0 to 470 percent and for storm volumes range from 34.4 to 416 percent using the calibrated parameters. A sensitivity analysis was done on selected parameters to determine the effect of a change in a parameter value on time of peak, storm peak, and storm volume for one gaged subbasin.

The results of the parameter sensitivity and error analyses from the initial model calibration were used to recalibrate the parameters. The mean absolute errors for storm peaks for the five subbasins range from 47.1 to 297 percent and for storm volumes range from 27.6 to 193 percent using the recalibrated parameters.

The model produced better results for simulation of the larger storm peaks and storm volumes than for 


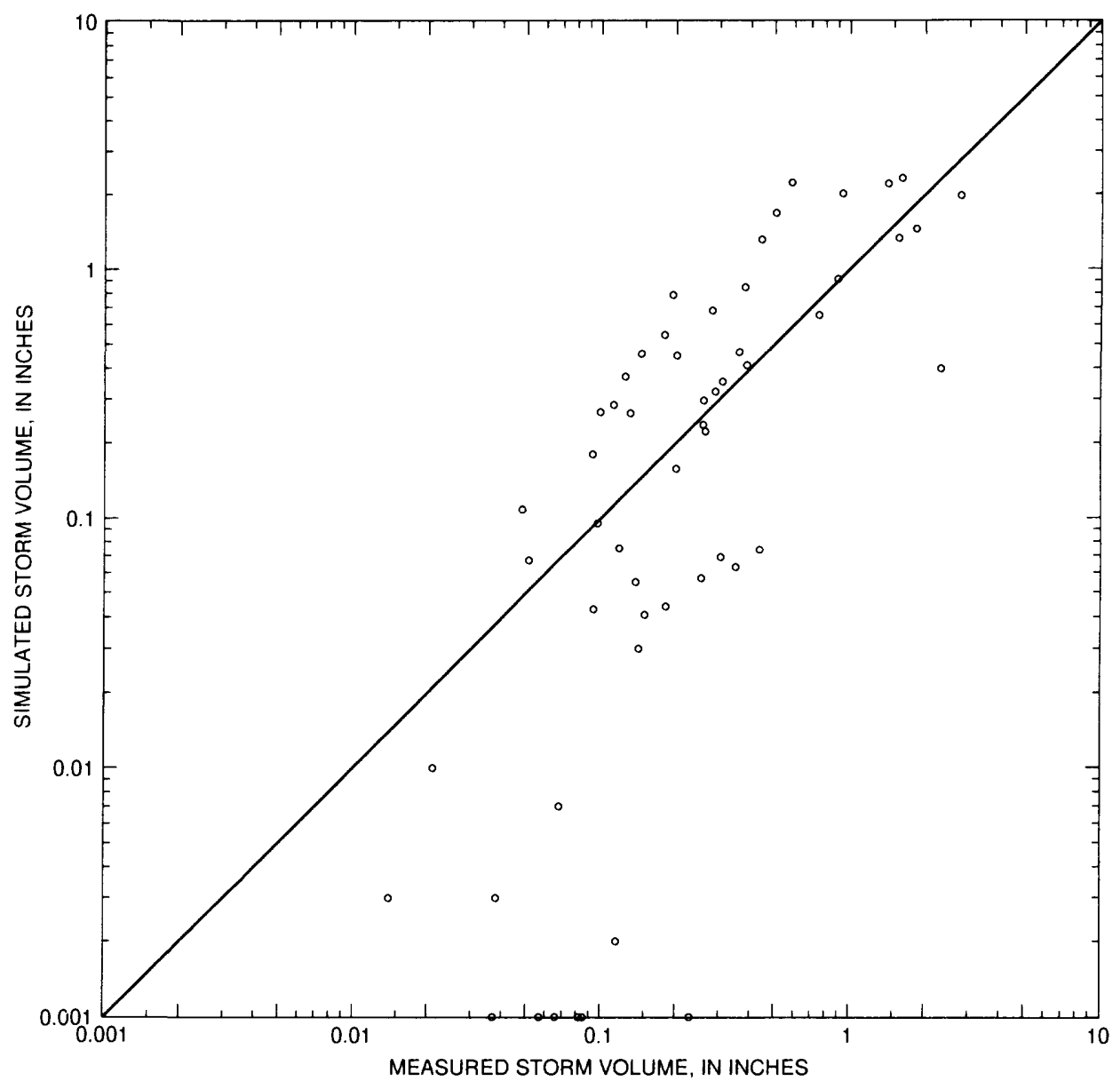

Figure 18. Measured storm volumes and simulated storm volumes using recalibrated parameters.

simulation of the smaller storm peaks and storm volumes, especially after an extended period of no runoff. The parameters can be transferred to the 23 ungaged subbasins with the same range in error expected. However, additional data collection and model refinement could decrease the model errors. In the study area, a wide variation in runoff was produced from similar magnitudes of measured rainfall. Continuous discharge data, improved stage-discharge rating tables, and more storm data could improve model calibration.

\section{REFERENCES CITED}

Chow, V.T., Maidment, D.R., and Mays, L.W., 1988, Applied hydrology: New York, McGraw-Hill, 572 p.

Dinicola R.S., 1990, Characterization and simulation of rainfall-runoff relations for headwater basins in western King and Shohomish Counties, Washington: U.S. Geological Survey Water-Resources Investigations Report 89-4052, $52 \mathrm{p}$.
Lumb, A.L., McCammon, R.B., and Kittle, J.L., 1994, Users manual for an expert system (HSPEXP) for calibration of the Hydrologic Simulation Program-FORTRAN: U.S. Geological Survey Water-Resources Investigations Report 94-4168, $58 \mathrm{p}$.

National Oceanic and Atmospheric Administration, 1990, Climatological data annual summary, Texas: Asheville, N.C., v. 95 , no. 13,77 p.

Shearman, J.O., 1990, Users manual for WSPRO-a computer model for water surface profile computations (Hydraulic computer program HY-7): U.S. Federal Highway Administration, Publication No. FHWA-IP$89-027,177 \mathrm{p}$.

U.S. Department of Agriculture, Soil Conservation Service, 1977, Soil survey of Parker County, Texas: $90 \mathrm{p}$. 1978, Soil survey of Montague County, Texas: $115 \mathrm{p}$. 1981, Soil survey of Tarrant County, Texas: 218 p.

U.S. Environmental Protection Agency, 1992, Hydrologic Simulation Program-FORTRAN users manual for release 10: $660 \mathrm{p}$. 
Table 1. Process-related model parameters for the Hydrologic Simulation Program—FORTRAN

[ET, evapotranspiration]

\begin{tabular}{llccrl}
\hline Parameter & \multicolumn{1}{c}{ Description $^{\prime}$} & Default & Minimum & Maximum & \multicolumn{1}{c}{ Units } \\
\hline AGWS & Initial active ground-water storage & None & 0 & None & Inches \\
AGWETP & Available ET satisfied by active ground water & 0 & 0 & 1.0 & None \\
AGWRC & Active ground-water recession rate & None & .001 & 1.0 & Per day \\
BASETP & Available ET satisfied by base flow & 0 & 0 & 1.0 & None \\
& & & & & \\
CEPSC & Interception storage capacity & 0 & 0 & 1.0 & Inches \\
DEEPFR & Fraction of inflow that enters inactive ground water & 0 & 0 & 1.0 & None \\
INFEXP & Infiltration equation exponent & 2.0 & 0 & 10.0 & None \\
INFILD & Ratio of maximum and mean infiltration capacities & 2.0 & 1.0 & 2.0 & None \\
& & & & & \\
INFILT & Index to infiltration capacity of soil & None & .0001 & 100.0 & Inches per hour \\
INTFW & Interflow inflow & None & 0 & None & None \\
IRC & Interflow recession rate & None & 0 & 1.0 & Per day \\
KVARY & Nonexponential ground-water recession rate & 0 & 0 & None & Per inch \\
& & & & & \\
LSUR & Length of assumed overland flow plane & None & 1.0 & None & Feet \\
LZETP & Lower zone ET & 0 & 0 & 1.0 & None \\
LZS & Initial lower zone storage & None & 0 & None & Inches \\
LZSN & Lower zone nominal storage & None & .01 & 100.0 & Inches \\
NSUR & Manning's n for assumed overland flow plane & .1 & .001 & 1.0 & None \\
SLSUR & Slope of assumed overland flow plane & None & .000001 & 10.0 & Feet per foot \\
UZS & Initial upper zone storage & None & 0 & None & Inches \\
UZSN & Upper zone nominal storage & None & .01 & 10.0 & Inches \\
\hline
\end{tabular}

I The users manual for Hydrologic Simulation Program-FORTRAN (U.S. Environmental Protection Agency, 1992) provides a more complete description of each parameter.

Table 2. Basin-related model parameters for the Hydrologic Simulation Program—FORTRAN

[PERLND, pervious land segment; IMPLND, impervious land segment; FTABLE, table of depth, surface area, volume, and discharge for each reach]

\begin{tabular}{lll}
\hline Parameter & \multicolumn{1}{c}{ Description $^{\prime}$} & \multicolumn{1}{c}{ Units $^{-1}$} \\
\hline AREA & Drainage area of each PERLND or IMPLND & Acres \\
LEN & Reach length & Miles \\
DEPTH & FTABLE depth & Feet \\
SAREA & FTABLE surface area & Acres \\
& & \\
VOL & FTABLE volume & Acre-feet \\
DISCH & FTABLE discharge & Cubic feet per second \\
\hline
\end{tabular}

' The users manual for Hydrologic Simulation Program-FORTRAN (U.S. Environmental Protection Agency, 1992) provides a more complete description of each parameter. 
Table 3. Gaged subbasins in the West Fork Trinity River Basin upstream from Lake Worth

\begin{tabular}{clc}
\hline $\begin{array}{c}\text { U.S. Geological Survey } \\
\text { station number }\end{array}$ & \multicolumn{1}{c}{ Station name } & $\begin{array}{c}\text { Drainage area } \\
\text { (square miles) }\end{array}$ \\
\hline 08042900 & Beans Creek at Wizard Wells & 36.0 \\
$(08042950$ & Big Creek near Chico & 50.0 \\
08044135 & Garrett Creek near Paradise & 52.7 \\
08044140 & Salt Creek near Paradise & 53.0 \\
08044800 & Walnut Creck at Reno & 62.6 \\
\hline
\end{tabular}

Table 4. Basin-related parameters for each gaged subbasin

[Land segments are characterized and designated by a 3-digit descriptor. The first digit designates soil permeability: I, low permeability (less than 2 inches/hour); 2 , moderately low permeability (more than 2 inches/hour; X, all permeabilities (or permeability not characterized). The second digil designates land cover: (, crop; F, forest: P, pasture; X, all land covers (or land cover not characterized). The third digit designates watershed slope: F, flat, less than 3 percent; S, steep, more than 3 percent; X. all slopes (or slope not characterized). For example, a land segment characterized by soils of moderately low permeability, a forest cover, and a steep slope has the descriplor $2 \mathrm{FS}$. A land segment for which only land cover is characterized (as crop) has the descriptor XCX.

AREA, land-segment drainage area; LEN, reach length; mi, miles; FTABLE, table of depth (DEPTH), surface area (SAREA), volume (VOL), and discharge (DISCFI) for a reach; ft, feet; acre-ft, acre-fect; $\mathrm{ft}^{3} / \mathrm{s}$, cubic feet per second; --, no value]

\begin{tabular}{|c|c|c|c|c|c|}
\hline Parameter $^{\prime}$ & Beans Creek & Big Creek & Garrett Creek & Salt Creek & Walnut Creek \\
\hline \multicolumn{6}{|c|}{ Reach 1} \\
\hline \multicolumn{6}{|l|}{ AREA (acres) } \\
\hline $\mathrm{ICF}$ & 1,307 & 844 & 0 & 104 & 175 \\
\hline ICS & 128 & 131 & 0 & 80 & 141 \\
\hline $1 \mathrm{FF}$ & 2,037 & 4,622 & 0 & 133 & 469 \\
\hline IFS & 381 & 808 & 0 & 129 & 329 \\
\hline $1 \mathrm{PF}$ & 4.782 & 6,736 & 0 & 253 & 580 \\
\hline IPS & 899 & 1,402 & 0 & 171 & 382 \\
\hline $2 \mathrm{C} F$ & 127 & 130 & 2,701 & 2,856 & 3,106 \\
\hline $2 \mathrm{CS}$ & 9 & 27 & 338 & 1,317 & 179 \\
\hline $2 \mathrm{FF}$ & 54 & 1,048 & 4,409 & 4,802 & 3,513 \\
\hline $2 \mathrm{FS}$ & 6 & 194 & 765 & 2,476 & 403 \\
\hline $2 \mathrm{PF}$ & 302 & 1,158 & 5.220 & 5,273 & 5,610 \\
\hline 2PS & 43 & 340 & 795 & 2,403 & 569 \\
\hline LEN (mi) & 7.71 & 9.44 & 13.8 & 11.8 & 8.55 \\
\hline \multicolumn{6}{|l|}{ FTABLE } \\
\hline DEPTH $(f t)$ & $0-20.0$ & $0-20.0$ & $0-20.0$ & $0-20.0$ & $0-16.0$ \\
\hline SAREA (acres) & $0-23.4$ & $0-57.2$ & $0-45.0$ & $0-71.2$ & $0-51.8$ \\
\hline VOL (acre-ft) & $0-421$ & $0-687$ & $0-567$ & $0-1,024$ & $0-498$ \\
\hline $\operatorname{DISCH}\left(\mathrm{ft}^{3} / \mathrm{s}\right)$ & $0-2,400$ & $0-10,600$ & $0-3,360$ & $0-12,100$ & $0-7,180$ \\
\hline \multicolumn{6}{|c|}{ Reach 2} \\
\hline \multicolumn{6}{|l|}{ AREA (acres) } \\
\hline $1 \mathrm{CF}$ & 734 & 699 & 52 & 0 & 148 \\
\hline $1 \mathrm{CS}$ & 76 & 34 & 12 & 0 & 61 \\
\hline $1 \mathrm{FF}$ & 902 & 1,976 & 136 & 0 & 779 \\
\hline IFS & 169 & 195 & 13 & 0 & 416 \\
\hline
\end{tabular}


Table 4. Basin-related parameters for each gaged subbasin-Continued

\begin{tabular}{|c|c|c|c|c|c|}
\hline Parameter $^{1}$ & Beans Creek & Big Creek & Garrett Creek & Salt Creek & Walnut Creek \\
\hline \multicolumn{6}{|c|}{ Reach $2-$ Continued } \\
\hline IPF & 1,900 & 3,088 & 77 & 0 & 690 \\
\hline IPS & 347 & 201 & 12 & 0 & 341 \\
\hline $2 \mathrm{CF}$ & 288 & 250 & 2,189 & 3,456 & 2,309 \\
\hline $2 \mathrm{CS}$ & 39 & 36 & 334 & 489 & 89 \\
\hline $2 \mathrm{FF}$ & 314 & 568 & 4,540 & 3,449 & 2,514 \\
\hline $2 \mathrm{FS}$ & 76 & 144 & 738 & 898 & 122 \\
\hline $2 \mathrm{PF}$ & 647 & 861 & 6,159 & 4,671 & 4,043 \\
\hline $2 \mathrm{PS}$ & 98 & 209 & 864 & 948 & 190 \\
\hline LEN (mi) & 6.74 & 6.49 & 13.3 & 4.4 & 2.70 \\
\hline \multicolumn{6}{|l|}{ FTABLE } \\
\hline DEPTH $(\mathrm{ft})$ & $0-20.0$ & $0-20.0$ & $0-20.0$ & $0-20.0$ & $0-20.0$ \\
\hline SAREA (acres) & $0-19.2$ & $0-39.3$ & $0-43.5$ & $0-56.5$ & () -36.0 \\
\hline VOL (acre-ft) & $0-331$ & $0-472$ & $0-548$ & $0-979$ & $0-426$ \\
\hline $\operatorname{DISCH}\left(\mathrm{ft}^{3} / \mathrm{s}\right)$ & $0-2,000$ & $0-11,600$ & $0-3,360$ & $0-9,500$ & $0-18,100$ \\
\hline \multicolumn{6}{|c|}{ Reach 3} \\
\hline AREA (acres) & & & & -- & \\
\hline $1 \mathrm{CF}$ & 568 & 282 & 0 & -- & 0 \\
\hline $1 \mathrm{CS}$ & 222 & 20 & 0 & -- & 0 \\
\hline $1 \mathrm{FF}$ & 1.439 & 1,229 & 0 & -- & 0 \\
\hline $1 \mathrm{FS}$ & 532 & 225 & 0 & -- & 0 \\
\hline $1 \mathrm{PF}$ & 2,192 & 2,296 & 0 & -- & 0 \\
\hline 1PS & 804 & 420 & 0 & -- & 0 \\
\hline $2 \mathrm{CF}$ & 188 & 319 & 956 & -- & 3,300 \\
\hline $2 \mathrm{CS}$ & 9 & 22 & 109 & -- & 93 \\
\hline $2 \mathrm{FF}$ & 618 & 477 & 1,082 & -- & 3,247 \\
\hline $2 \mathrm{FS}$ & 26 & 89 & 224 & -- & 205 \\
\hline $2 \mathrm{PF}$ & 729 & 730 & 1,782 & -- & 5,746 \\
\hline $2 \mathrm{PS}$ & 33 & 171 & 270 & -- & 306 \\
\hline LEN (mi) & 3.88 & 4.37 & 2.64 & -- & 4.19 \\
\hline \multicolumn{6}{|l|}{ FTABLE } \\
\hline DEPTH (ft) & $0-20.0$ & $0-20.0$ & $0-20.0$ & -- & $0-20.0$ \\
\hline SAREA (acres) & $0-29.9$ & $0-68.9$ & $0-18.2$ & - & $0-50.8$ \\
\hline VOL (acre-ft) & $0-543$ & $0-847$ & $0-236.8$ & -- & $0-610$ \\
\hline DISC II $\left(\mathrm{ft}^{3} / \mathrm{s}\right)$ & $0-4,760$ & $0-20,000$ & $0-4,410$ & -- & $0-22,500$ \\
\hline
\end{tabular}

${ }^{1}$ The users manual for Hydrologic Simulation Program--FORTRAN (U.S. Environmental Protection Agency, 1992) provides a more complete description of each parameter. 

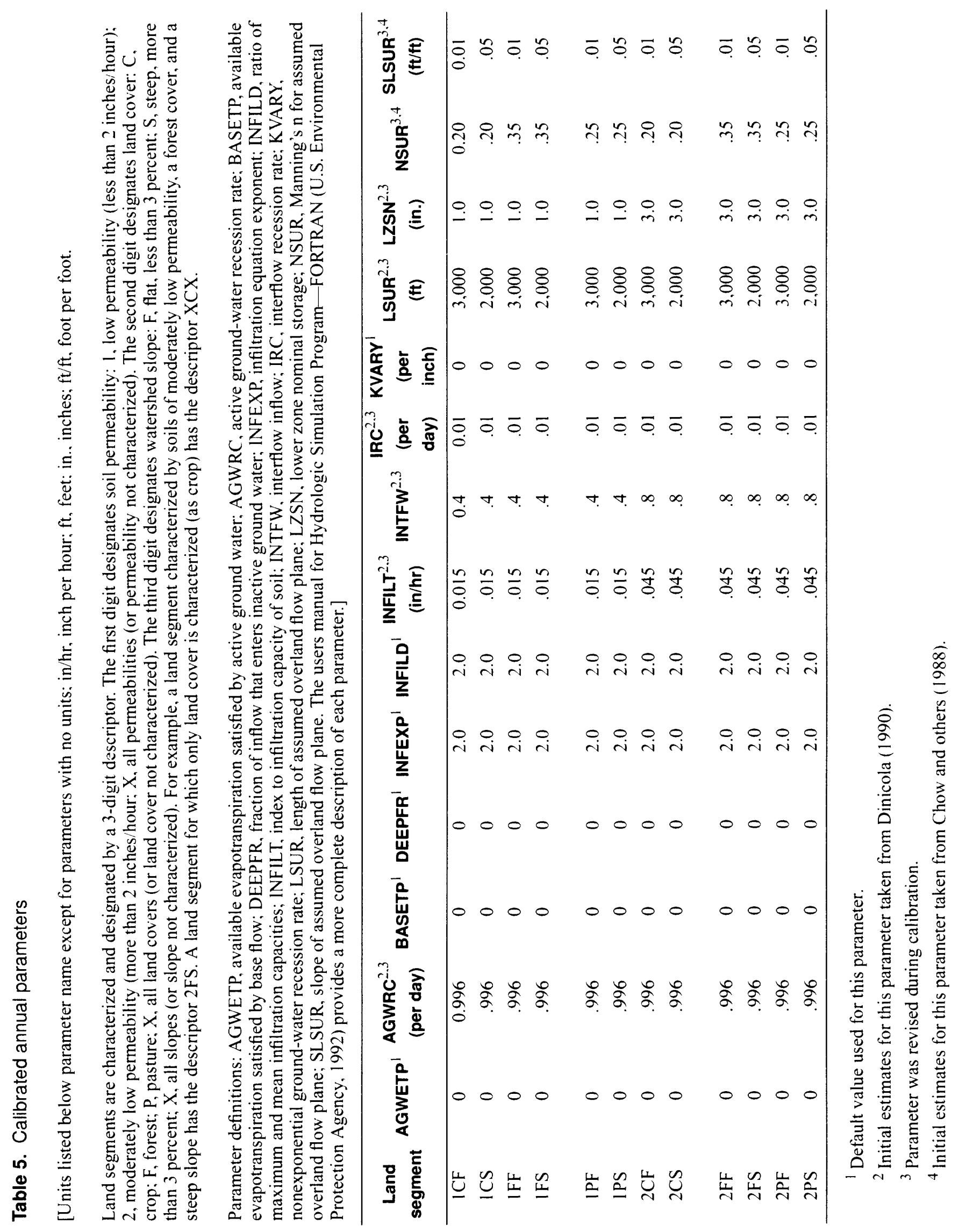
Table 6. Calibrated monthly parameters

[Units listed below parameter name except for parameters with no units; in., inches.

Land segments are characterized and designated by a 3-digit descriptor. The first digit designates soil permeability: 1, low permeability (less than 2 inches/hour); 2 , moderately low permeability (more than 2 inches/hour; X, all permeabilities (or permeability not characterized). The second digit designates land cover: C, crop; F, forest; P, pasture; X, all land covers (or land cover not characterized). The third digit designates watershed slope: F, flat, less than 3 percent; S, steep, more than 3 percent: X, all slopes (or slope not characterized). For example, a land segment characterized by soils of moderately low permeability, a forest cover, and a steep slope has the descriptor $2 \mathrm{FS}$. A land segment for which only land cover is characterized (as crop) has the descriptor XCX.

Parameter definitions: CEPSC, interception storage capacity; LZETP, Iower zone evapotranspiration; UZSN, upper zone nominal storage. The users manual for Hydrologic Simulation Program - FORTRAN (U.S. Environmental Protection Agency, 1992) provides a more complete description of each parameter.

\begin{tabular}{|c|c|c|c|c|c|c|c|c|c|c|c|c|}
\hline $\begin{array}{c}\text { Land } \\
\text { segment }\end{array}$ & Jan & Feb & Mar & Apr & May & June & July & Aug & Sept & Oct & Nov & Dec \\
\hline \multicolumn{13}{|c|}{$\begin{array}{c}\text { CEPSC } \\
\text { (in.) }\end{array}$} \\
\hline $\mathrm{XCX}$ & 0.05 & 0.05 & 0.05 & 0.09 & 0.14 & 0.18 & 0.24 & 0.28 & 0.24 & 0.18 & 0.12 & 0.08 \\
\hline XFX & .11 & .11 & .16 & .18 & .24 & .28 & .32 & .32 & .28 & .22 & .18 & .14 \\
\hline XPX & .08 & .09 & .10 & .12 & .18 & .22 & .26 & .26 & .22 & .18 & .12 & .08 \\
\hline \multicolumn{13}{|c|}{ LZETP $^{1,2}$} \\
\hline $\mathrm{XCX}$ & .2 & .3 & .5 & .6 & .6 & .7 & .8 & .9 & .8 & .7 & .5 & .3 \\
\hline XFX & .3 & .4 & .6 & .7 & .7 & .8 & .9 & .9 & .9 & .7 & .6 & .4 \\
\hline XPX & .2 & .3 & .5 & .6 & .6 & .7 & .8 & .9 & .8 & .6 & .5 & .3 \\
\hline \multicolumn{13}{|c|}{$\begin{array}{c}\operatorname{UZSN}^{1.2} \\
\text { (in.) }\end{array}$} \\
\hline $1 X X$ & .1 & .1 & .2 & .2 & .3 & .4 & .5 & .6 & .5 & .4 & .3 & .2 \\
\hline $2 X X$ & .2 & .2 & .4 & .4 & .5 & .6 & .7 & .8 & .7 & .6 & .5 & .4 \\
\hline
\end{tabular}

I Initial estimates for this parameter taken from Dinicola (1990).

2 Parameter was revised during calibration. 


\section{Table 7. Initial condition values for model calibration}

[Land segments are characterized and designated by a 3-digit descriptor. The first digit designates soil permeability: 1, low permeability (less than 2 inches/hour); 2, moderately low permeability (more than 2 inches/hour; X, all permeabilities (or permeability not characterized). The second digit designates land cover: $C$, crop: F, forest; P, pasture; X, all land covers (or land cover not characterized). The third digit designates watershed slope: F, flat, less than 3 percent; S, steep, more than 3 percent; X, all slopes (or slope not characterized). For example, a land segment characterized by soils of moderately low permeability, a forest cover, and a steep slope has the descriptor $2 \mathrm{FS}$. A land segment for which only land cover is characterized (as crop) has the descriptor XCX.

AGWS, active ground-water storage; LZS, lower zone storagc; UZS, upper zone storage. The users manual for Hydrologic Simulation Program-FORTRAN (U.S. Environmental Protection Agency, 1992) provides a more complete description of each parameter. in., inches]

\begin{tabular}{|c|c|c|c|c|c|}
\hline Station & Water year & Land segment & $\begin{array}{c}\text { AGWS }^{1.2} \\
\text { (in.) }\end{array}$ & $\begin{array}{c}\text { LZS }^{1.2} \\
\text { (in.) }\end{array}$ & $\begin{array}{c}\text { UZS }^{1.2} \\
\text { (in.) }\end{array}$ \\
\hline \multirow[t]{4}{*}{ Beans Creek } & 1993 & $1 \mathrm{XX}$ & 0.01 & 0.5 & 0.1 \\
\hline & & $2 \mathrm{XX}$ & .01 & .5 & .1 \\
\hline & 1994 & $1 X X$ & .2 & 2.0 & .3 \\
\hline & & $2 X X$ & .2 & 2.0 & .3 \\
\hline \multirow[t]{4}{*}{ Big Creek } & 1993 & $1 X X$ & .01 & .5 & .1 \\
\hline & & $2 X X$ & .01 & .5 & .1 \\
\hline & 1994 & $1 X X$ & .2 & 2.0 & .3 \\
\hline & & $2 X X$ & .2 & 2.0 & .3 \\
\hline \multirow[t]{4}{*}{ Garrett Creek } & 1993 & $1 X X$ & .6 & 3.0 & .4 \\
\hline & & $2 x x$ & .6 & 3.0 & .4 \\
\hline & 1994 & $1 X X$ & .6 & 3.0 & .4 \\
\hline & & $2 X X$ & .6 & 3.0 & .4 \\
\hline \multirow[t]{4}{*}{ Salt Creek } & 1993 & $1 X X$ & .6 & 3.0 & .4 \\
\hline & & $2 \mathrm{XX}$ & .6 & 3.0 & .4 \\
\hline & 1994 & $1 X X$ & .2 & 2.0 & .3 \\
\hline & & $2 X X$ & .2 & 2.0 & .3 \\
\hline \multirow[t]{4}{*}{ Walnut Creek } & 1993 & $I X X$ & .6 & 3.0 & .4 \\
\hline & & $2 X X$ & .6 & 3.0 & .4 \\
\hline & 1994 & $1 X X$ & .2 & 2.0 & .3 \\
\hline & & $2 X X$ & .2 & 2.0 & .3 \\
\hline
\end{tabular}

\footnotetext{
'Initial estimates for this parameter taken from Dinicola (1990).

${ }^{2}$ Parameter was revised during calibration.
} 


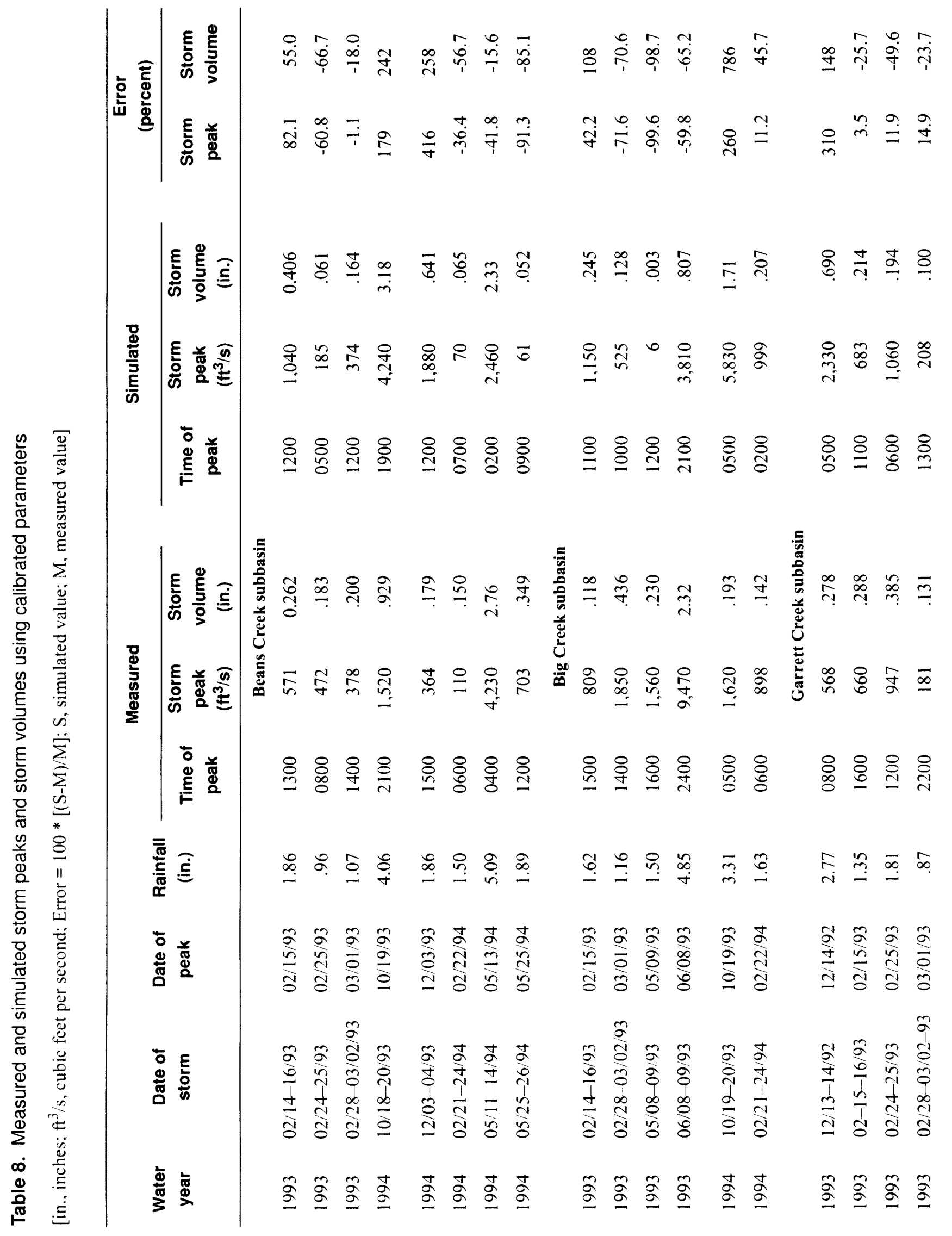




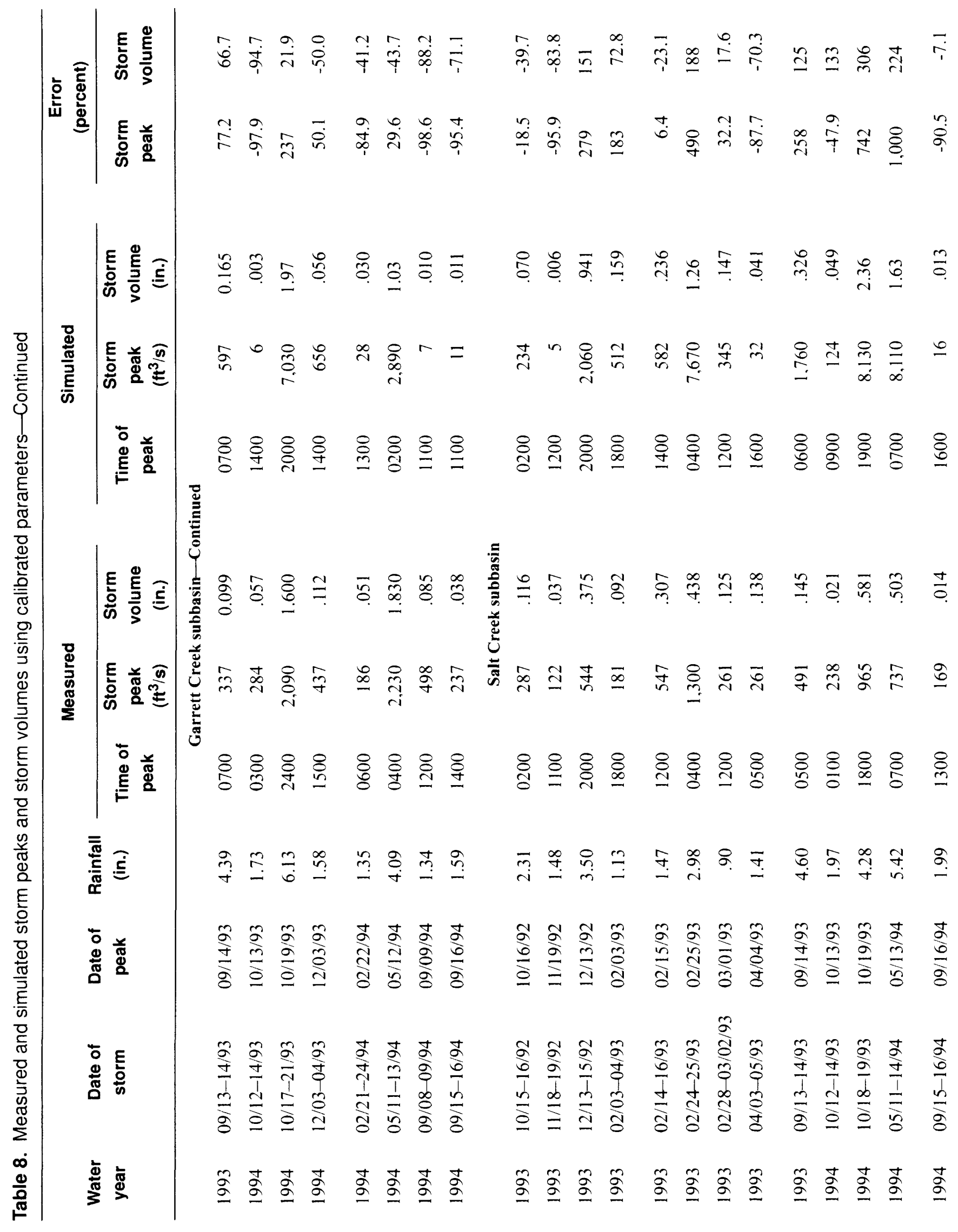




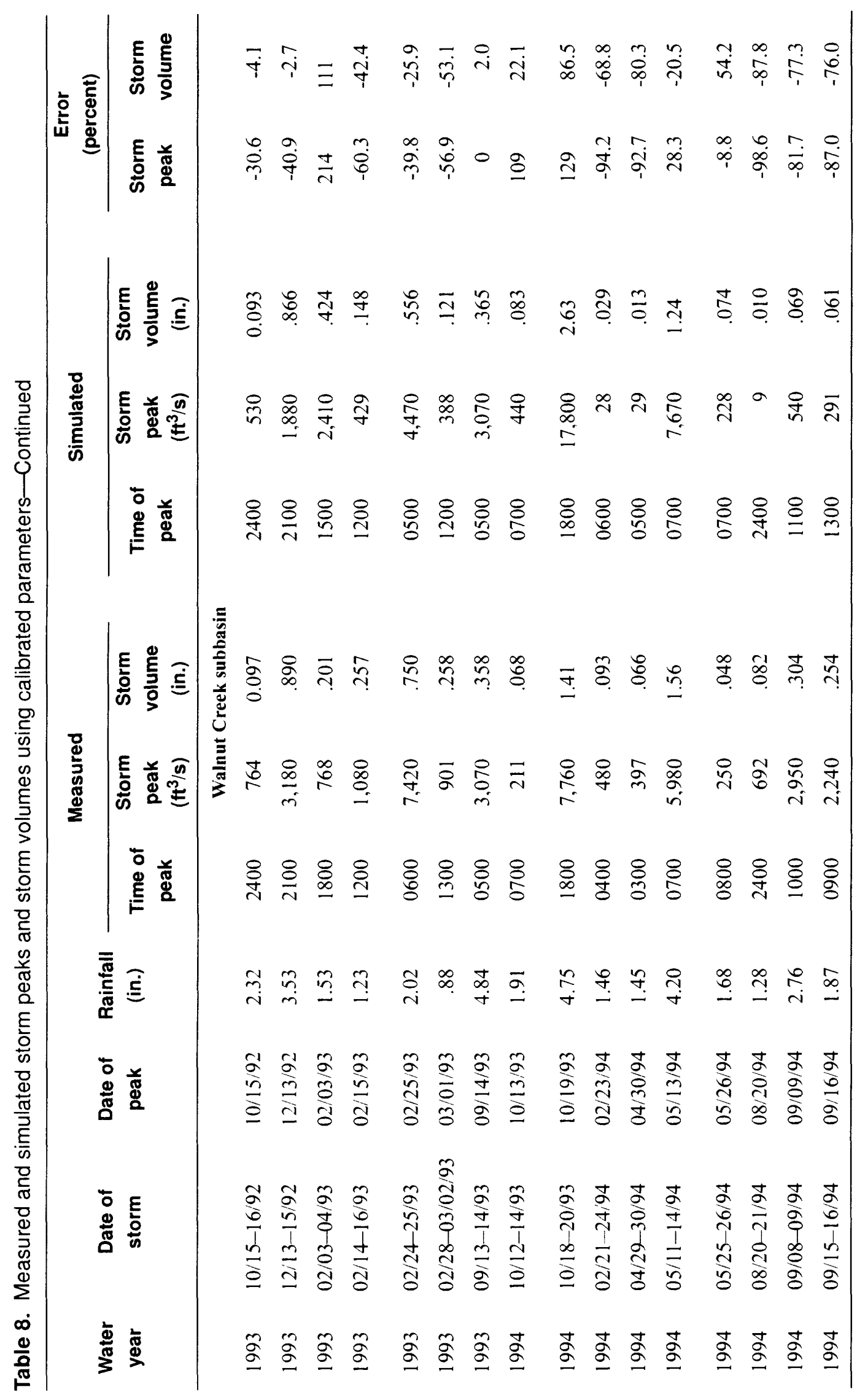


Table 9. Mean absolute errors and biases of storm peaks and storm volumes using calibrated parameters

$[$ Mean absolute error $=100 *[\Sigma(|\mathrm{S}-\mathrm{M}|) / \mathrm{M}] / \mathrm{N} ;$ bias $=100 *[\Sigma(\mathrm{S}-\mathrm{M}) / \mathrm{M}] / \mathrm{N} ; \mathrm{S}$, simulated value; $\mathrm{M}$, measured value; $\mathrm{N}$, number of values]

\begin{tabular}{|c|c|c|c|c|c|}
\hline \multirow[b]{2}{*}{ Station } & \multirow{2}{*}{$\begin{array}{l}\text { Water } \\
\text { year }\end{array}$} & \multicolumn{2}{|c|}{ Storm peaks } & \multicolumn{2}{|c|}{ Storm volumes } \\
\hline & & $\begin{array}{l}\text { Mean absolute error } \\
\text { (percent) }\end{array}$ & $\begin{array}{c}\text { Bias } \\
\text { (percent) }\end{array}$ & $\begin{array}{l}\text { Mean absolute error } \\
\text { (percent) }\end{array}$ & $\begin{array}{c}\text { Bias } \\
\text { (percent) }\end{array}$ \\
\hline \multirow[t]{2}{*}{ Beans Creek } & 1993 & 48.0 & 6.7 & 46.6 & -9.9 \\
\hline & 1994 & 153 & 85.2 & 132 & 68.6 \\
\hline \multirow[t]{2}{*}{ Big Creek } & 1993 & 68.3 & -47.2 & 85.5 & -31.7 \\
\hline & 1994 & 136 & 136 & 416 & 416 \\
\hline \multirow[t]{2}{*}{ Garrett Creek } & 1993 & 83.5 & 83.5 & 62.8 & 23.2 \\
\hline & 1994 & 99.0 & -8.6 & 58.7 & -52.4 \\
\hline \multirow[t]{2}{*}{ Salt Creek } & 1993 & 161 & $1 I 6$ & 85.6 & 9.7 \\
\hline & 1994 & 470 & 401 & 168 & 164 \\
\hline \multirow[t]{2}{*}{ Walnut Creek } & 1993 & 63.2 & 6.9 & 34.4 & -2.2 \\
\hline & 1994 & 81.0 & -21.9 & 63.7 & -8.0 \\
\hline
\end{tabular}

Table 10. Monthly distribution of errors of storm peaks and storm volumes using calibrated parameters

$[$ Error $=100 *[(\mathrm{~S}-\mathrm{M}) / \mathrm{S}] ; \mathrm{S}$, simulated value; $\mathrm{M}$, measured value; --, no storms $]$

\begin{tabular}{|c|c|c|c|c|}
\hline \multirow{2}{*}{ Month } & \multicolumn{2}{|c|}{ Storm-peak errors } & \multicolumn{2}{|c|}{ Storm-volume errors } \\
\hline & Positive & Negative & Positive & Negative \\
\hline January & - & -- & - & - \\
\hline February & 8 & 7 & 6 & 9 \\
\hline March & 3 & 2 & 1 & 4 \\
\hline April & -- & 2 & -- & 2 \\
\hline May & 3 & 4 & 2 & 5 \\
\hline June & -- & 1 & -- & I \\
\hline July & - & -- & -- & -- \\
\hline August & -- & 1 & -- & 1 \\
\hline September & 3 & 5 & 2 & 6 \\
\hline October & 6 & 4 & 7 & 3 \\
\hline November & -- & 1 & -- & 1 \\
\hline December & 4 & 1 & 3 & 2 \\
\hline Total & 27 & 28 & 21 & 34 \\
\hline
\end{tabular}


Table 11. Sensitivity of selected parameters

[Parameter definitions: AGWETP, available evapotranspiration satisfied by active ground water; AGWRC, active groundwater recession rate; BASETP, available evapotranspiration satisfied by base flow; DEEPFR, fraction of inflow that enters inactive ground water; INFEXP, infiltration equation exponent; INFILD, ratio of maximum and mean infiltration capacities; INFILT, index to infiltration capacity of soil; INTFW, interflow inflow; IRC, interflow recession rate; KVARY, nonexponential ground-water recession rate; LSUR, length of assumed overland flow plane; LZSN, lower zone nominal storage; NSUR, Manning's $n$ for assumed overland flow plane; SLSUR, slope of assumed overland flow plane; CEPSC, interception storage capacity; LZETP, lower zone evapotranspiration; UZSN, upper zone nominal storage; DISCH, FTABLE discharge; VOL, FTABLE volume; AGWS, initial active ground-water storage; LZS, initial lower zone storage; UZS, initial upper zone storage: FTABLE, table of depth, surface area, volume, and discharge for each reach. The users manual for Hydrologic Simulation Program—FORTRAN (U.S. Environmental Protection Agency, 1992) provides a more complete description of each parameter.

$\mathrm{ft}^{3} / \mathrm{s}$, cubic feet per second; in., inches; change $=100 *[(\mathrm{~A}-1) / 1] ; \mathrm{A}=$ adjusted value; 1 = initial value; --, undefined change $]$

\begin{tabular}{|c|c|c|c|c|c|c|c|c|}
\hline $\begin{array}{l}\text { Parameter } \\
\text { adjusted }\end{array}$ & $\begin{array}{l}\text { Initial } \\
\text { value }\end{array}$ & $\begin{array}{l}\text { Adjusted } \\
\text { value }\end{array}$ & $\begin{array}{l}\text { Change in } \\
\text { parameter } \\
\text { (percent) }\end{array}$ & $\begin{array}{c}\text { Time of } \\
\text { peak }\end{array}$ & $\begin{array}{c}\text { Storm } \\
\text { peak } \\
\left(\mathrm{ft}^{3} / \mathrm{s}\right)\end{array}$ & $\begin{array}{c}\text { Change } \\
\text { in storm } \\
\text { peak } \\
\text { (percent) }\end{array}$ & $\begin{array}{c}\text { Storm } \\
\text { volume } \\
\text { (in.) }\end{array}$ & $\begin{array}{c}\text { Change } \\
\text { in storm } \\
\text { volume } \\
\text { (percent) }\end{array}$ \\
\hline \multicolumn{9}{|c|}{ Annual process-related parameters } \\
\hline AGWETP & 0.0 & 0.1 & -- & 1800 & 15,800 & 2.6 & 4.69 & 2.6 \\
\hline AGWRC & .996 & .906 & -9.0 & 1800 & 15,500 & .7 & 4.73 & 3.5 \\
\hline BASETP & .0 & .1 & -- & 1800 & 15,800 & 2.6 & 4.66 & 2.0 \\
\hline DEEPFR & .0 & .1 & -- & 1800 & 15,400 & .0 & 4.56 & -.2 \\
\hline INFEXP & 2.0 & 1.5 & -25.0 & 1800 & 15,900 & 3.2 & 4.80 & 5.0 \\
\hline INFILD & 2.0 & 1.5 & -25.0 & 1800 & 15,200 & -1.3 & 4.57 & .0 \\
\hline INFILT & $.015, .045$ & $.022, .068$ & 50.0 & 1800 & 13,000 & -15.6 & 3.80 & -16.9 \\
\hline INTFW & .4 .8 & $.6,1.2$ & 50.0 & 1800 & 14,400 & -6.5 & 4.85 & 6.1 \\
\hline IRC & .01 & .1 & 900.0 & 1800 & 15,200 & -1.3 & 4.43 & -3.1 \\
\hline KVARY & .0 & .2 & -- & 1800 & 15,400 & .0 & 4.57 & .0 \\
\hline LSUR & $2,000,3,000$ & $3,000,4,000$ & $50.0,33.3$ & 1800 & 13,300 & -13.6 & 4.35 & -4.8 \\
\hline LZSN & $1.0,3.0$ & $1.5,4.5$ & 50.0 & 1800 & 13,300 & -13.6 & 3.67 & -19.7 \\
\hline NSUR & $.20, .35, .25$ & $.30, .45, .35$ & $50.0,28.6,40.0$ & 1800 & 13,000 & -15.6 & 4.33 & -5.3 \\
\hline SLSUR & $.01, .05$ & $.02, .07$ & $100.0,40.0$ & 1800 & 18,300 & 18.8 & 4.80 & 5.0 \\
\hline \multicolumn{9}{|c|}{ Monthly process-related parameters } \\
\hline CEPSC & $.05-.32$ & $.15-.42$ & $200.0-31.2$ & 1800 & 15,100 & -1.9 & 4.37 & -4.4 \\
\hline LZETP & $.2-.9$ & $.3-1.0$ & $50.0-11.1$ & 1800 & 15,000 & -2.6 & 4.68 & 2.4 \\
\hline UZSN & $.1-.8$ & $.2-.9$ & $50.0-2.5$ & 1800 & 14,100 & -8.4 & 4.03 & -11.8 \\
\hline \multicolumn{9}{|c|}{ Basin-related parameters } \\
\hline DISCH & $0-22,500$ & $0-11,250$ & -50.0 & 1800 & 13,400 & -13.0 & 4.50 & -1.5 \\
\hline VOL & $0-610$ & $0-1220$ & 100.0 & 1800 & 12,100 & -21.4 & 4.42 & -3.3 \\
\hline \multicolumn{9}{|c|}{ Initial process-related conditions } \\
\hline AGWS & .6 & .3 & -50.0 & 1800 & 15,400 & .0 & 4.57 & .0 \\
\hline LZS & 3.0 & 2.0 & -33.3 & 1800 & 15,400 & .0 & 4.49 & -1.8 \\
\hline UZS & .4 & .2 & -50.0 & 1800 & 15,400 & .0 & 4.55 & -.4 \\
\hline None & -- & -- & .0 & 1800 & 15,400 & .0 & 4.57 & .0 \\
\hline
\end{tabular}




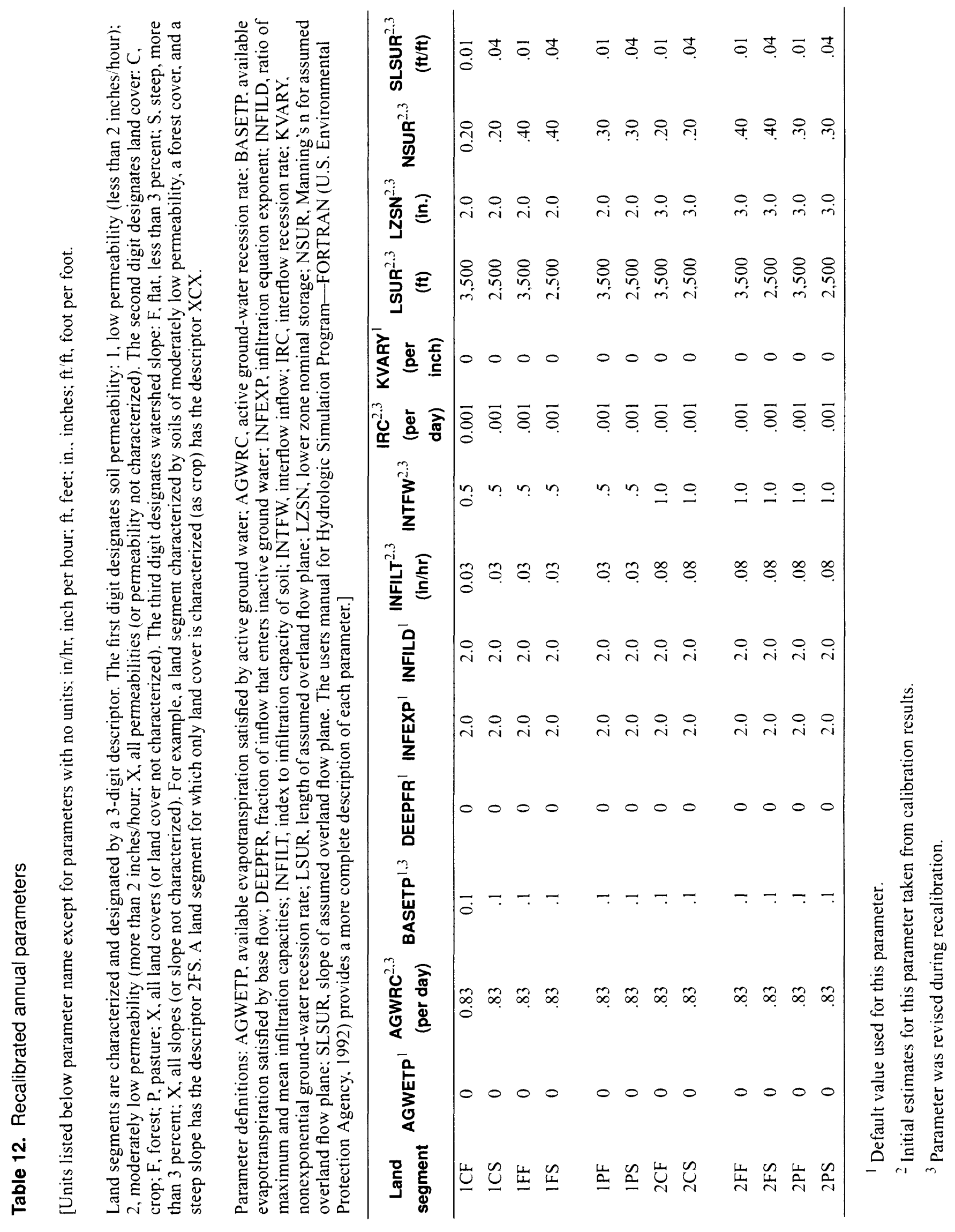


Table 13. Recalibrated monthly parameters

[Units listed below parameter name except for parameters with no units; in., inches.

Land segments are characterized and designated by a 3-digit descriptor. The first digit designates soil permeability: 1, low permeability (less than 2 inches/hour); 2, moderately low permeability (more than 2 inches/hour; X, all permeabilities (or permeability not characterized). The second digit designates land cover: C, crop; F, forest; P, pasture; X, all land covers (or land cover not characterized). The third digit designates watershed slope: $F$, flat, less than 3 percent; $S$, steep, more than 3 percent: X, all slopes (or slope not characterized). For example, a land segment characterized by soils of moderately low permeability, a forest cover, and a steep slope has the descriptor 2FS. A land segment for which only land cover is characterized (as crop) has the descriptor XCX.

Parameter definitions: CEPSC, interception storage capacity; LZETP, lower zone evapotranspiration; UZSN, upper zone nominal storage. The users manual for Hydrologic Simulation Program--FORTRAN (U.S. Environmental Protection Agency, 1992) provides a more complete description of each parameter]

\begin{tabular}{|c|c|c|c|c|c|c|c|c|c|c|c|c|}
\hline $\begin{array}{l}\text { Land } \\
\text { segment }\end{array}$ & Jan & Feb & Mar & Apr & May & June & July & Aug & Sept & Oct & Nov & Dec \\
\hline \multicolumn{13}{|c|}{$\begin{array}{c}\text { CEPSC } \\
\text { (in.) }\end{array}$} \\
\hline $\mathrm{XCX}$ & 0.05 & 0.05 & 0.05 & 0.09 & 0.14 & 0.18 & 0.24 & 0.28 & 0.24 & 0.18 & 0.12 & 0.08 \\
\hline XFX & .11 & .11 & .16 & .18 & .24 & .28 & .32 & .32 & .28 & .22 & .18 & .14 \\
\hline $\mathrm{XPX}$ & .08 & .09 & .10 & .12 & .18 & .22 & .26 & .26 & .22 & .18 & .12 & .08 \\
\hline \multicolumn{13}{|c|}{ LZETP $^{1.2}$} \\
\hline$X \subset X$ & .2 & .3 & .4 & .5 & .6 & .7 & .8 & .9 & .7 & .6 & .5 & .3 \\
\hline XFX & .3 & .4 & .5 & .6 & .7 & .8 & .9 & .9 & .8 & .7 & .6 & .4 \\
\hline XPX & .2 & .3 & .4 & .5 & .6 & .7 & .8 & .9 & .7 & .7 & .5 & .3 \\
\hline \multicolumn{13}{|c|}{$\begin{array}{c}\mathbf{U Z S N}^{1,2} \\
\text { (in.) }\end{array}$} \\
\hline $1 X X$ & .1 & .1 & .2 & .2 & .2 & .3 & .4 & .4 & .3 & .3 & .3 & .2 \\
\hline $2 X X$ & .2 & .2 & .3 & .3 & .4 & .5 & .6 & 6 & .5 & .4 & .4 & .3 \\
\hline
\end{tabular}

I Initial cstimates for this parameter taken from calibration results.

2 Parameter was revised during recalibration. 
Table 14. Initial condition values for model recalibration

[Land segments are characterized and designated by a 3-digit descriptor. The first digit designates soil permeability: 1, low permeability (less than 2 inches/hour); 2, moderately low permeability (more than 2 inches/hour; X, all permeabilities (or permeability not characterized). The second digit designates land cover: C, crop; F, forest: P, pasture; X, all land covers (or land cover not characterized). The third digit designates watershed slope: F, flat, less than 3 percent; S, steep, more than 3 percent; X, all slopes (or slope not characterized). For example, a land segment characterized by soils of moderately low permeability, a forest cover, and a steep slope has the descriptor 2FS. A land segment for which only land cover is characterized (as crop) has the descriptor XCX.

AGWS, active ground-water storage; LZS, lower zone storage; UZS, upper zone storage. The users manual for Hydrologic Simulation Program-FORTRAN (U.S. Environmental Protection Agency, 1992) provides a more complete description of each parameter. in., inches]

\begin{tabular}{|c|c|c|c|c|c|}
\hline Station & Water year & Land segment & $\begin{array}{c}\text { AGWS }^{1.2} \\
\text { (in.) }\end{array}$ & $\begin{array}{l}\operatorname{LZS}^{1.2} \\
\text { (in.) }\end{array}$ & $\begin{array}{l}\text { UZS }^{1.2} \\
\text { (in.) }\end{array}$ \\
\hline \multirow[t]{4}{*}{ Beans Creek } & 1993 & $1 X X$ & 0.02 & 0.5 & 0.11 \\
\hline & & $2 X X$ & .02 & .6 & .12 \\
\hline & 1994 & $1 X X$ & .01 & .5 & .01 \\
\hline & & $2 \mathrm{XX}$ & .01 & .7 & .02 \\
\hline \multirow[t]{4}{*}{ Big Creek } & 1993 & $1 \mathrm{XX}$ & .02 & .5 & .11 \\
\hline & & $2 \mathrm{XX}$ & .02 & .6 & .12 \\
\hline & 1994 & $1 \mathrm{XX}$ & .01 & 3 & .01 \\
\hline & & $2 \mathrm{XX}$ & .01 & .5 & .01 \\
\hline \multirow[t]{4}{*}{ Garrett Creek } & 1993 & $1 X X$ & .12 & .7 & .11 \\
\hline & & $2 X X$ & .12 & 1.1 & .12 \\
\hline & 1994 & $1 \mathrm{XX}$ & .01 & .4 & .01 \\
\hline & & $2 \mathrm{XX}$ & .02 & 1.0 & .03 \\
\hline \multirow[t]{4}{*}{ Salt Creek } & 1993 & $1 X X$ & .02 & .7 & .05 \\
\hline & & $2 X X$ & .02 & 1.7 & .08 \\
\hline & 1994 & $1 \mathrm{XX}$ & .03 & .5 & .03 \\
\hline & & $2 X X$ & .05 & 1.3 & .05 \\
\hline \multirow[t]{4}{*}{ Walnut Creek } & 1993 & $1 \mathrm{XX}$ & .52 & 2.7 & .21 \\
\hline & & $2 \mathrm{XX}$ & .62 & 3.1 & .32 \\
\hline & 1994 & IXX & .02 & .7 & .01 \\
\hline & & $2 X X$ & .02 & 1.1 & .02 \\
\hline
\end{tabular}

\footnotetext{
${ }^{1}$ Initial estimates for this parameter taken from calibration results.

${ }^{2}$ Parameter was revised during recalibration.
} 


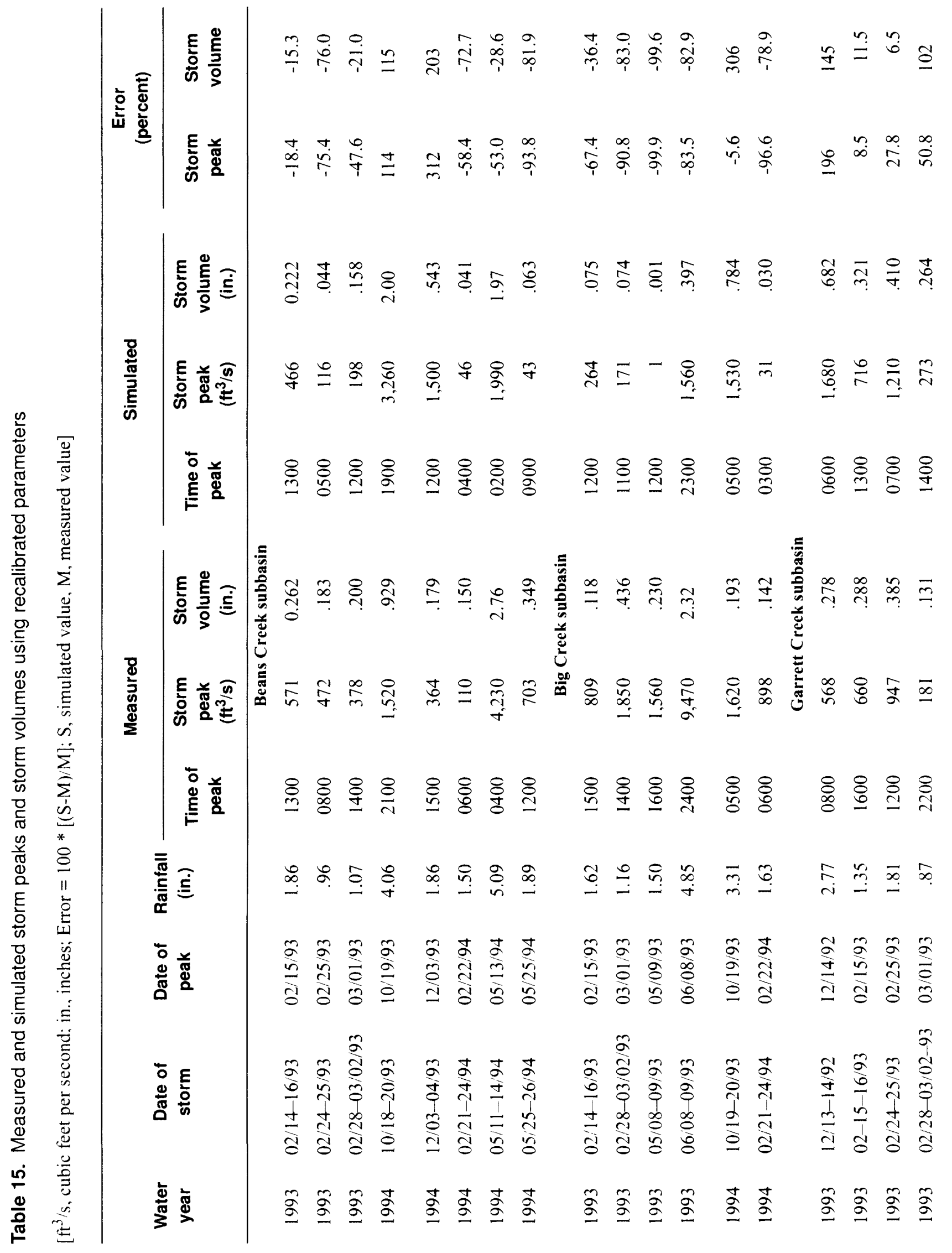




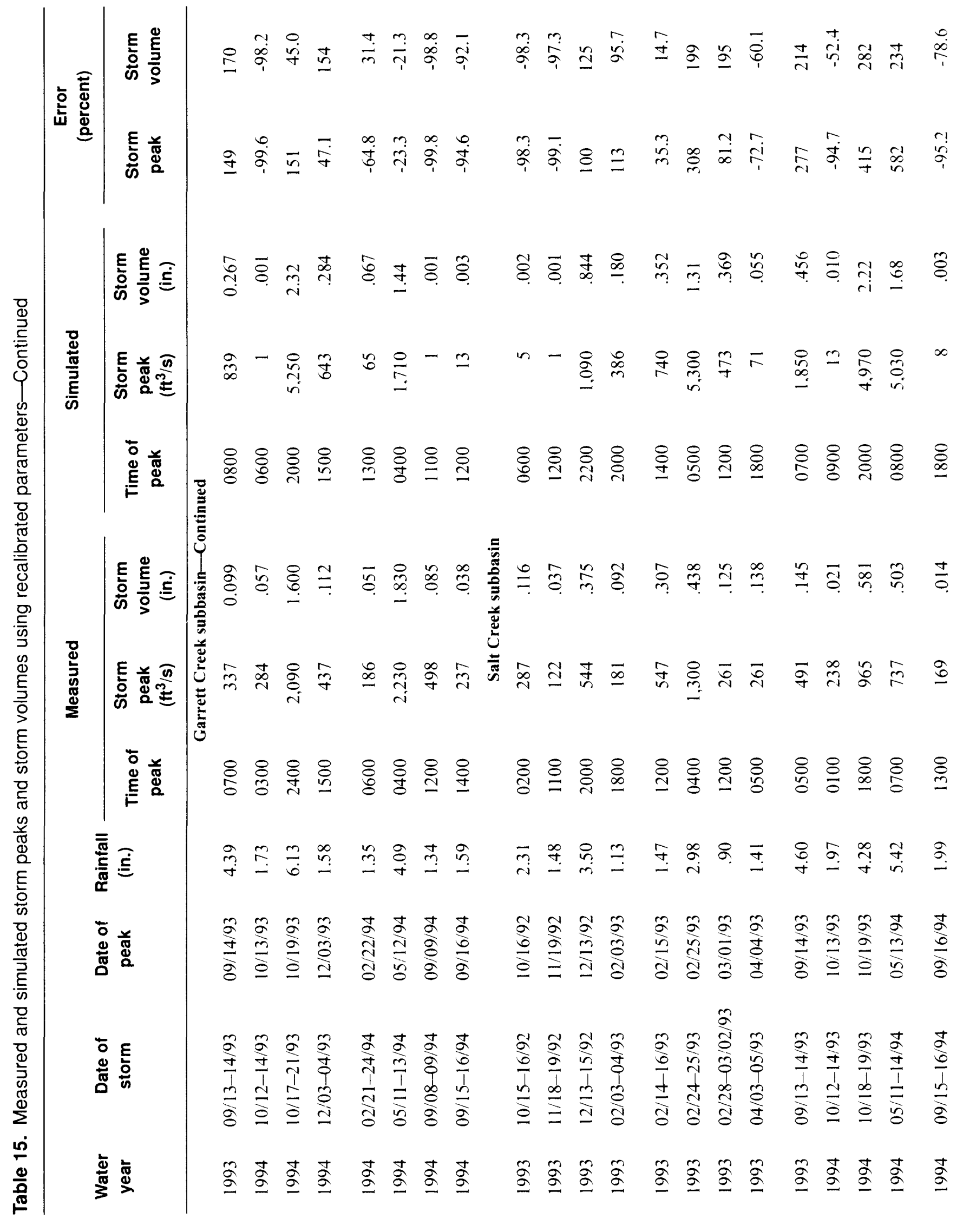




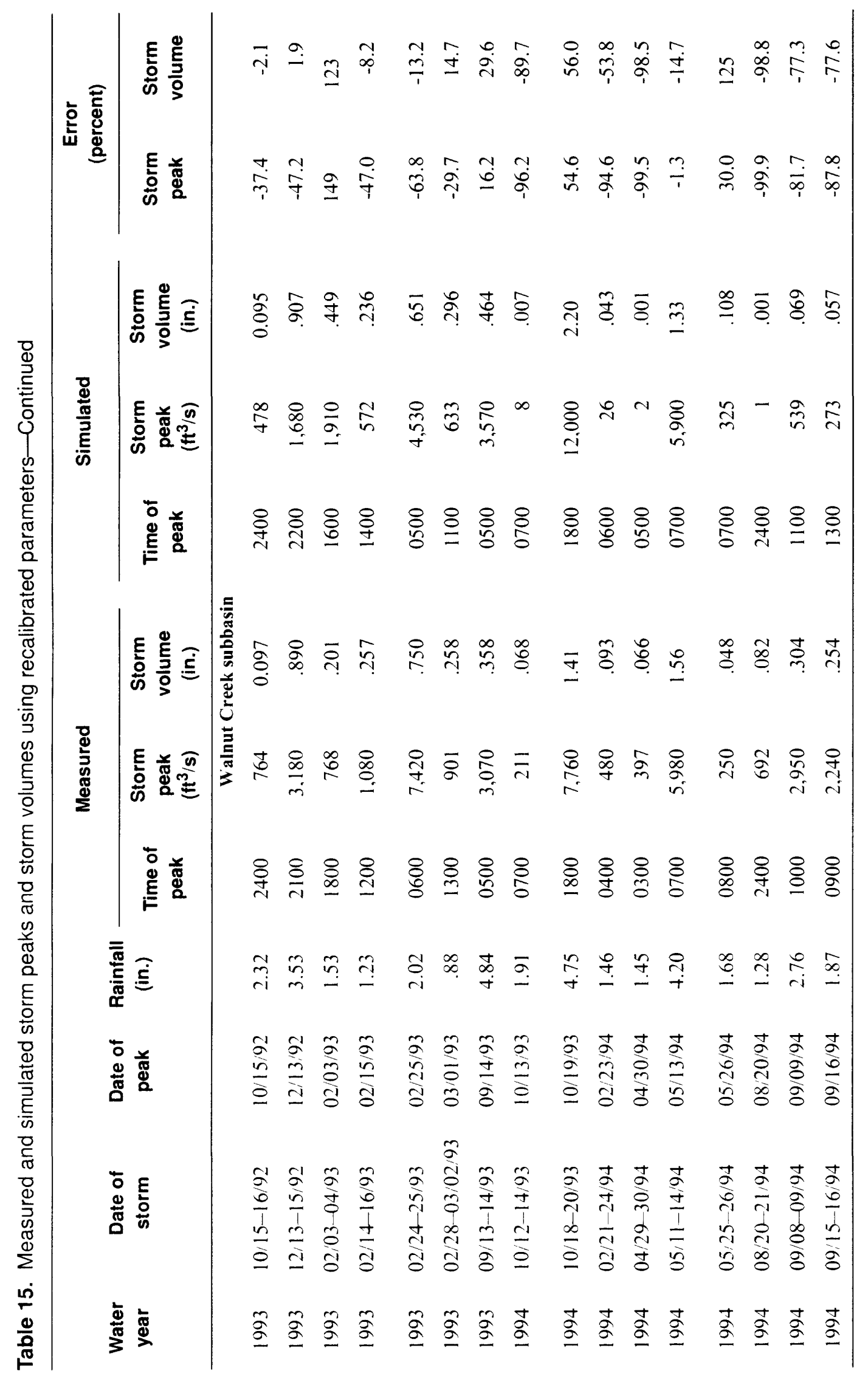


Table 16. Mean absolute errors and biases of storm peaks and storm volumes using recalibrated parameters

[Mean absolute error $=100 *[\Sigma(|\mathrm{S}-\mathrm{M}|) / \mathrm{M}] / \mathrm{N} ;$ bias $=100 *[\Sigma(\mathrm{S}-\mathrm{M}) / \mathrm{M}] / \mathrm{N} ; \mathrm{S}$, simulated value; $\mathrm{M}$, measured value; $\mathrm{N}$, number of values]

\begin{tabular}{|c|c|c|c|c|c|}
\hline \multirow[b]{2}{*}{ Station } & \multirow[b]{2}{*}{ Water year } & \multicolumn{2}{|c|}{ Storm peaks } & \multicolumn{2}{|c|}{ Storm volumes } \\
\hline & & $\begin{array}{l}\text { Mean absolute error } \\
\text { (percent) }\end{array}$ & $\begin{array}{c}\text { Bias } \\
\text { (percent) }\end{array}$ & $\begin{array}{l}\text { Mean absolute error } \\
\text { (percent) }\end{array}$ & $\begin{array}{c}\text { Bias } \\
\text { (percent) }\end{array}$ \\
\hline \multirow[t]{2}{*}{ Bcans Creek } & 1993 & 47.1 & -471 & 37.4 & -37.4 \\
\hline & 1994 & 126 & 44.2 & 100 & 27.1 \\
\hline \multirow[t]{2}{*}{ Big Creek } & 1993 & 85.4 & -85.4 & 75.6 & -75.6 \\
\hline & 1994 & 51.1 & -51.1 & 193 & 114 \\
\hline \multirow[t]{2}{*}{ Garrett ( reek } & 1993 & 86.4 & 86.4 & 86.9 & 86.9 \\
\hline & 1994 & 82.9 & -26.3 & 77.4 & -11.7 \\
\hline \multirow[t]{2}{*}{ Salt Creek } & 1993 & 132 & 71.6 & 122 & 65.4 \\
\hline & 1994 & 297 & 202 & 162 & 96.3 \\
\hline \multirow[t]{2}{*}{ Walnut Creek } & 1993 & 55.7 & -8.6 & 27.6 & 20.9 \\
\hline & 1994 & 71.7 & -52.9 & 77.0 & -36.7 \\
\hline
\end{tabular}

Table 17. Monthly distribution of errors of storm peaks and storm volumes using recalibrated parameters

$[$ Error $=100 *[(\mathrm{~S}-\mathrm{M}) / \mathrm{S}] ; \mathrm{S}$, simulated value; $\mathrm{M}$, measured value;,-- no storms $]$

\begin{tabular}{|c|c|c|c|c|}
\hline \multirow{2}{*}{ Month } & \multicolumn{2}{|c|}{ Storm-peak errors } & \multicolumn{2}{|c|}{ Storm-volume errors } \\
\hline & Positive & Negative & Positive & Negative \\
\hline January & -- & - & - & -- \\
\hline February & 6 & 9 & 7 & 8 \\
\hline March & 2 & 3 & 3 & 2 \\
\hline April & -- & 2 & -- & 2 \\
\hline May & 2 & 5 & 2 & 5 \\
\hline June & -- & 1 & -- & 1 \\
\hline July & -- & -- & -- & -- \\
\hline August & - & 1 & -- & 1 \\
\hline September & 3 & 5 & 3 & 5 \\
\hline October & 4 & 6 & 5 & 5 \\
\hline November & -- & 1 & - & 1 \\
\hline December & 4 & 1 & 5 & -- \\
\hline Total & 21 & 34 & 25 & 30 \\
\hline
\end{tabular}

